\title{
Disposal of \\ Hazardous Wastes by In Situ Vitrification
}

\author{
S. S. Koegler
}

July 1987

Prepared for the U.S. Department of Energy under Contract DE-AC06-76RLO 1830

Pacific Northwest Laboratory Operated for the U.S. Department of Energy by Battelle Memorial Institute 


\section{DISCLAIMER}

This report was prepared as an account of work sponsored by an agency of the United States Government. Neither the United States Government nor any agency thereof, nor Battelle Memorial Institute, nor any of their employees, makes any warranty, expressed or implied, or assumes any legal liability or responsibility for the accuracy, completeness, or usefulness of any information, apparatus, product, or process disclosed, or represents that its use would not infringe privately owned rights. Reference herein to any specific commercial product, process, or service by trade name, trademark, manufacturer, or otherwise, does not necessarily constitute or imply its endorsement, recommendation, or favoring by the United States Government of any agency thereof, or Battelle Memorial Institute. The views and opinions of authors expressed herein do not necessarly state or reflect those of the United States Government or any agency thereof, or Battelle Memorial Institute.

\section{PACIFIC NORTHWEST LABORATORY operated by \\ BATTELLE MEMORIAL INSTITUTE for the \\ UNITED STATES DEPARTMENT OF ENERGY under Contract DE-AC06-76RLO 1830}

\begin{tabular}{|c|c|}
\hline \multicolumn{2}{|c|}{$\begin{array}{l}\text { Printed in the United States of America } \\
\text { Available from } \\
\text { National Technical Information Service } \\
\text { United States Department of Commerce } \\
5285 \text { Port Royal Road } \\
\text { Springfield, Virginia } 22161\end{array}$} \\
\hline \multicolumn{2}{|c|}{$\begin{array}{l}\text { NTIS Price Codes } \\
\text { Microfiche A01 }\end{array}$} \\
\hline \multicolumn{2}{|c|}{ Printed Copy } \\
\hline Pages & $\begin{array}{l}\text { Price } \\
\text { Codes }\end{array}$ \\
\hline $001-025$ & $\mathrm{~A} 02$ \\
\hline $026-050$ & $\mathrm{~A} 03$ \\
\hline $051-075$ & A04 \\
\hline $076-100$ & A05 \\
\hline $101-125$ & A06 \\
\hline $126-150$ & $\mathrm{~A} 07$ \\
\hline $151-175$ & $\mathrm{~A} 08$ \\
\hline $176-200$ & A09 \\
\hline $201-225$ & A010 \\
\hline $226-250$ & A011 \\
\hline $251-275$ & $\mathrm{~A} 012$ \\
\hline $276-300$ & $\mathrm{~A} 013$ \\
\hline
\end{tabular}


DISPOSAL OF HAZARDOUS WASTES

BY IN SITU VITRIFICATION

S. S. Koegler

July 1987

Prepared for

the U.S. Department of Energy

under Contract DE-AC06-76RLO 1830

Pacific Northwest Laboratory

Richland, Washingt on 99352 
. 
SUMMARY

An engineering-scale in situ vitrification (ISV) experiment was conducted to determine the feasibility of ISV technology for destruction of hazardous non-nuclear chemical wastes. Four simulated waste mixtures were placed in sealed one-liter metal containers and vitrified over a 23-hour period. The simulated waste mixtures were selected from a variety of Hanford waste types and sources typical of those that Hanford must dispose of off-site each year. The off gas from the experiment was analyzed for chemicals specific to the simulated wastes and destruction/removal efficiencies were calculated. The off-gas data indicated that concentrations of the targeted chemicals were within acceptable environmental release limits.

Following the experiment, the soil surrounding the vitrified block was sampled for specific chemicals to determine if chemical migration into the soil had occurred. The soil analyses indicated that small amounts of formaldehyde and methylethyl ketone migrated horizontally about $20 \mathrm{~cm}$ from the vitrification zone into the soil. However, the concentrations of the chemicals in the soil were less than $1 \mathrm{ppm}$, which is several orders of magnitude below Washington State regulatory limits for dangerous wastes.

The evaporation rate of the container contents was determined by in-can temperature and pressure data taken during the experiment. The time from when the can was breached by the molten glass until the contents were completely vaporized was 40 to 80 minutes. Applied to the large-scale ISV process, these data indicate that one 55-gallon drum of methylethyl ketone or three drums of antifreeze solution (50\% ethylene glycol) can be processed simultaneously without exceeding the large-scale system hood design or off-gas system criteria. Further work is necessary at the pilot-and large-scale level to verify the large-scale ISV process for destruction of larger quantities of combustible liquids in sealed containers. 


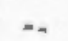

$\cdots$ 


\section{CONTENTS}

SUMMARY

INTRODUCTION

EXPERIMENTAL PROCEDURES

DESCRIPTION OF SIMULATED WASTES

TEST EQUIPMENT

OFF-GAS MEASUREMENTS $\ldots \ldots \ldots \ldots \ldots \ldots \ldots \ldots \ldots \ldots \ldots \ldots \ldots \ldots \ldots \ldots \ldots \ldots \ldots \ldots$

EXPERIMENTAL RESULTS $\ldots \ldots \ldots \ldots \ldots \ldots \ldots \ldots \ldots \ldots \ldots \ldots \ldots \ldots \ldots \ldots \ldots \ldots \ldots \ldots \ldots$

RELEASE OF CAN CONTENTS $\ldots \ldots \ldots \ldots \ldots \ldots \ldots \ldots \ldots \ldots \ldots \ldots \ldots \ldots \ldots \ldots \ldots \ldots \ldots \ldots$

Release Data for Can 1: Photographic Chemicals ............ 12

Release Data for Can 2: Pilot Plant Chemicals ............. 12

Release Data for Can 3: Antifreeze Solution .............. 15

Release Data for Can 4: Paint Shop Chemicals ............. 17

OFF-GAS ANALYSES $\ldots \ldots \ldots \ldots \ldots \ldots \ldots \ldots \ldots \ldots \ldots \ldots \ldots \ldots \ldots \ldots \ldots \ldots \ldots$

Off-Gas Analyses Can 1: Photographic Chemicals ............ 20

Off-Gas Analyses Can 2: Pilot Plant Chemicals .............. 21

Off-Gas Analyses Can 3: Antifreeze Solution .............. 21

Off-Gas Analyses Can 4: Paint Shop Chemicals .............. 21

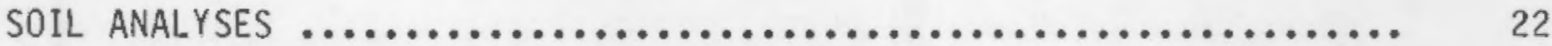

CONCLUSIONS AND RECOMMENDATIONS $\ldots \ldots \ldots \ldots \ldots \ldots \ldots \ldots \ldots \ldots \ldots \ldots \ldots \ldots \ldots \ldots \ldots$

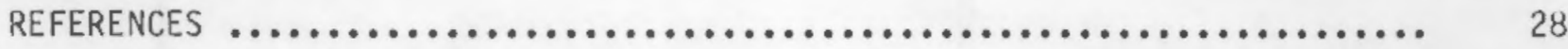




\section{FIGURES}

1 The Vitrification Process $\ldots \ldots \ldots \ldots \ldots \ldots \ldots \ldots \ldots \ldots \ldots \ldots \ldots \ldots \ldots \ldots \ldots \ldots$

2 Sample of Vitrified Soil $\ldots \ldots \ldots \ldots \ldots \ldots \ldots \ldots \ldots \ldots \ldots \ldots \ldots \ldots \ldots \ldots \ldots \ldots$

3 Engineering-Scale In Situ Vitrification $\ldots \ldots \ldots \ldots \ldots \ldots \ldots \ldots \ldots \ldots$

4 In Situ Vitrification $\ldots \ldots \ldots \ldots \ldots \ldots \ldots \ldots \ldots \ldots \ldots \ldots \ldots \ldots \ldots \ldots$

5 Sampling Equipment $\ldots \ldots \ldots \ldots \ldots \ldots \ldots \ldots \ldots \ldots \ldots \ldots \ldots \ldots \ldots \ldots \ldots \ldots \ldots$

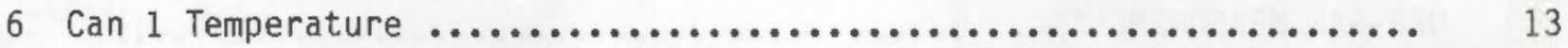

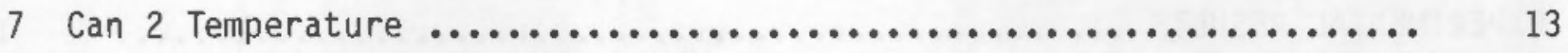

8 Can 2 Pressure $\ldots \ldots \ldots \ldots \ldots \ldots \ldots \ldots \ldots \ldots \ldots \ldots \ldots \ldots \ldots \ldots \ldots \ldots \ldots \ldots \ldots$

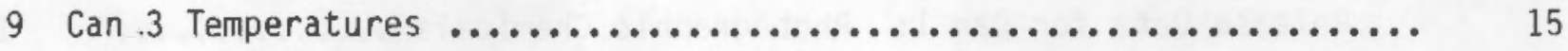

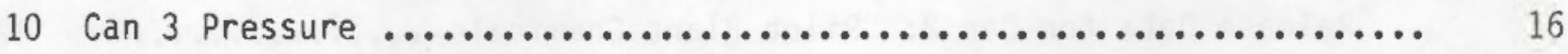

11 Can 4 Temperatures $\ldots \ldots \ldots \ldots \ldots \ldots \ldots \ldots \ldots \ldots \ldots \ldots \ldots \ldots \ldots \ldots \ldots \ldots \ldots$

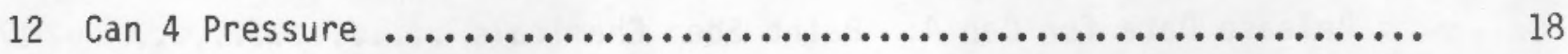

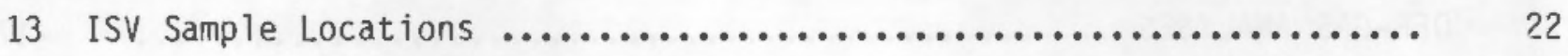




\section{TABLES}

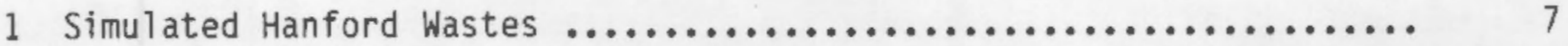

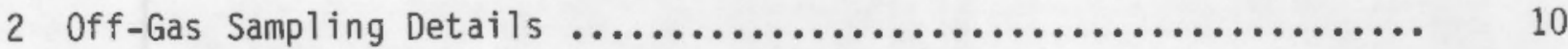

3 Can Contents Release Data ................................ 12

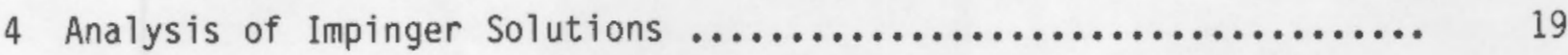

5 Soil Sampling Details $\ldots \ldots \ldots \ldots \ldots \ldots \ldots \ldots \ldots \ldots \ldots \ldots \ldots \ldots \ldots \ldots \ldots \ldots$

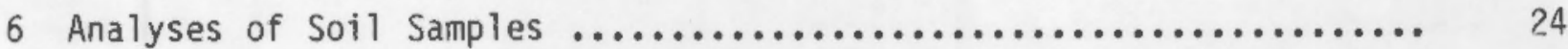




\section{INTRODUCTION}

Each year, hazardous non-nuclear chemical wastes generated at Hanford must be collected, stored, and disposed of off site at a hazardous material disposal site. The chemical wastes generated in CY 1985 contained many liquid inorganic, organic, and flammable materials considered dangerous wastes under Washington State Regulation. As such, they are subject to the allowable holding period of 90 days specified in Washington State and U.S. Environmental Protection Agency (EPA) regulations. Storage, packaging, and shipment of these wastes to an off-site facility is costly and necessitates a degree of risk in the area of regulatory compliance and future liability.

A more desirable and cost-effective approach would be to permanently dispose of or destroy the wastes on site. One candidate technology for hazardous waste disposal is in situ vitrification (ISV). The ISV process uses the Joule heating effect to create temperatures high enough to melt the soil of a disposal site and destroy or immobilize the chemicals placed in it.

Figure 1 illustrates the sequence of steps in the vitrification process. A square array of four molybdenum electrodes is inserted into the ground to the desired treatment depth. Because soil is not electrically conductive when the

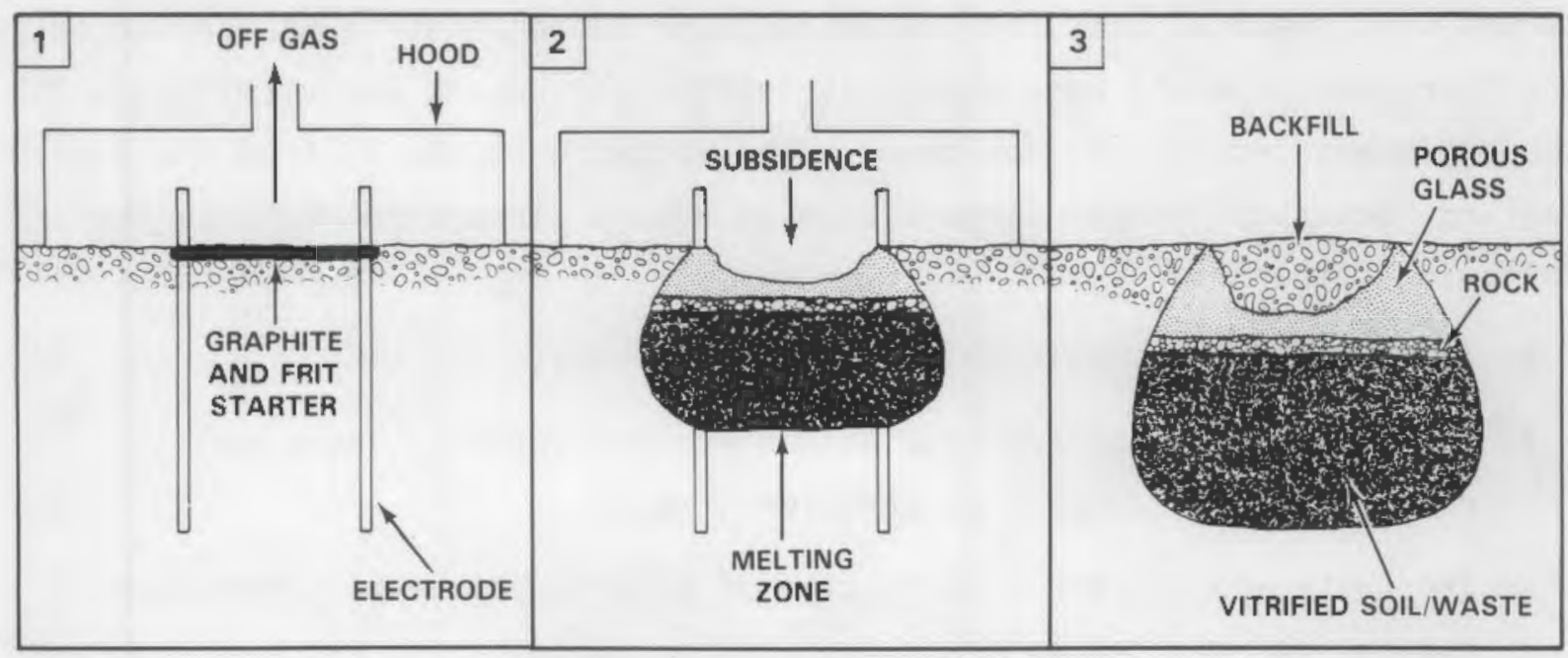

FIGURE 1. The Vitrification Process 
moisture has been driven off, a conductive mixture of flaked graphite and glass frit is placed among the electrodes to establish an electrical current in the starter path. The resultant power heats the starter path and surrounding soil to $2000^{\circ} \mathrm{C}$, well above the initial soil-melting temperatures of 1100 to $1400^{\circ} \mathrm{C}$. The graphite starter path is eventually consumed by oxidation, and the current is transferred to the molten soil, which is electrically conductive. As the molten or vitrified zone grows, it incorporates radionuclides and nonvolatile hazardous elements, such as heavy metals, and destroys organic components by pyrolysis. The pyrolized byproducts migrate to the surface of the vitrified zone where they combust in the presence of oxygen. A hood placed over the area being vitrified directs the gaseous effluents to an off-gas treatment system.

The ISV technology has been tested for in situ immobilization of radioactive and toxic substances placed in the soil, and is applicable to drummed or packaged wastes. The ISV process has the potential to destroy many of the hazardous chemicals which are generated at Hanford and are currently shipped off site for disposal. The vitrified soil is a chemically inert stable glass and crystalline product, as shown in Figure 2.

The objective of this exploratory research program was to determine the applicability of the ISV process for destroying or immobilizing hazardous chemicals that are generated at Hanford. An engineering-scale test was performed with chemical mixtures simulating four representative Hanford wastes. The four cans of waste were placed at incremental depths and vitrified using the engineering-scale ISV equipment. The wastes were chosen from the 1985 DOE Hanford "Generator Annual Dangerous Waste Report" in accordance with the following criteria:

- The waste must be able to be processed by ISV.

- The waste cannot be reactive or dangerous to process (such as reactive metals, ether, or perchloric acid).

- The waste should be representative of a large volume of current and continuing enerated wastes.

- The wastes should be selected from a variety of generators/contractors. 


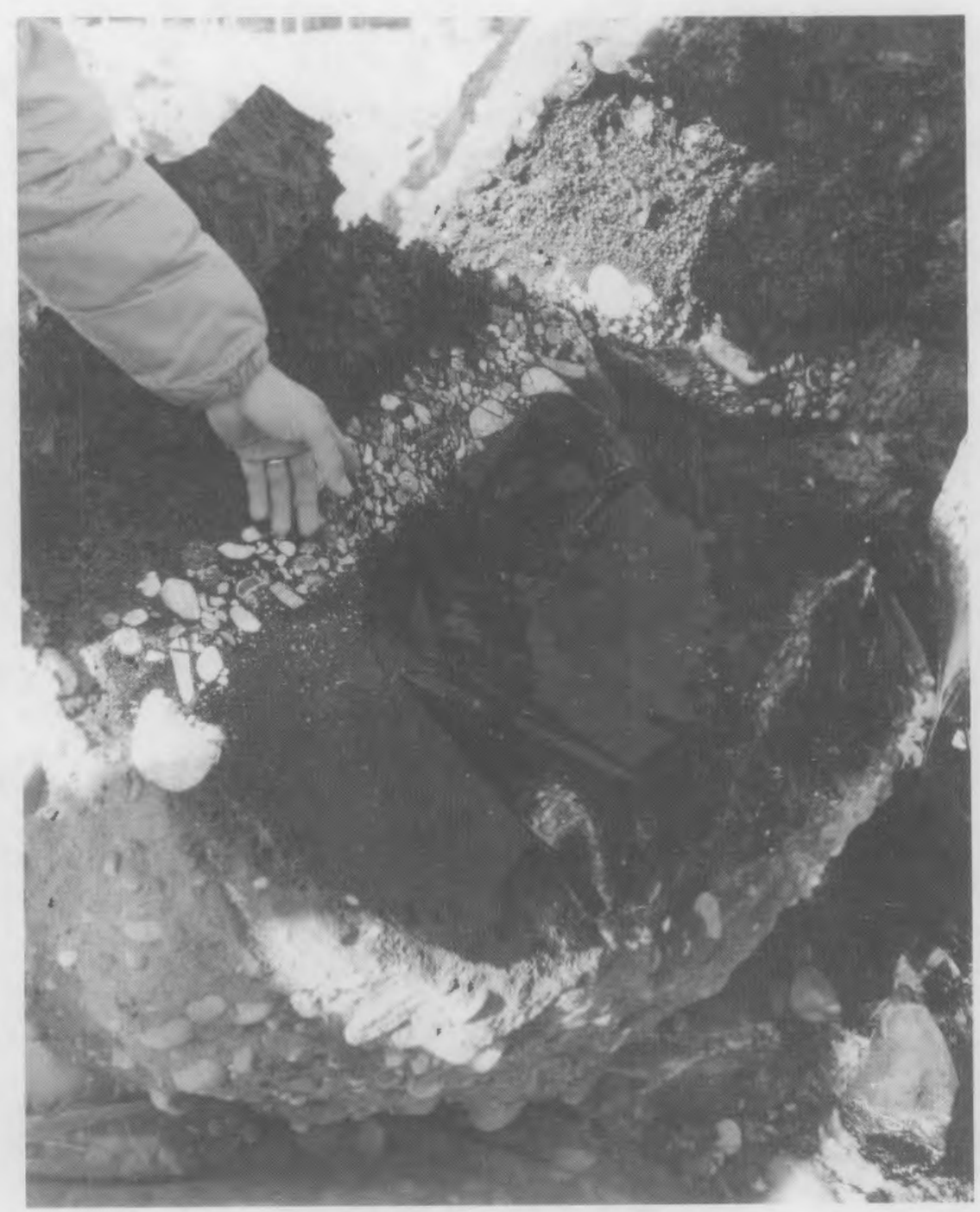

FIGURE 2. Sample of Vitrified Soil

Analyses of the ISV performance, including temperature measurements and off-gas samples generated by the destruction of each simulated waste, were used to assess the feasibility of ISV for routine destruction of Hanford hazardous chemical wastes. The cans were spaced by a sufficient depth of soil to permit the separation of the data between cans for individual analysis of each simulated waste. 


\section{EXPERIMENTAL PROCEDURES}

The engineering-scale ISV system consists of a soil-filled corrugated container in which the waste materials are buried and a $30-\mathrm{kW}$ electrical supply which provides power to the melt via molybdenum electrodes inserted in the soil around the materials (see Figure 3 ). The off gas from the process is sampled and treated before discharge to the atmosphere. In this experiment, the simulated wastes were placed in metal containers at 22-cm intervals to a depth of $1.2 \mathrm{~m}$ in Hanford soil. Temperatures around the containers and temperatures and pressure in the containers were monitored during the experiment. Samples of the soil and the off gas were taken during the experiment for later analysis to determine destruction or removal efficiency and possible soil migration of specific chemicals from the simulated hazardous wastes to the surrounding soil.

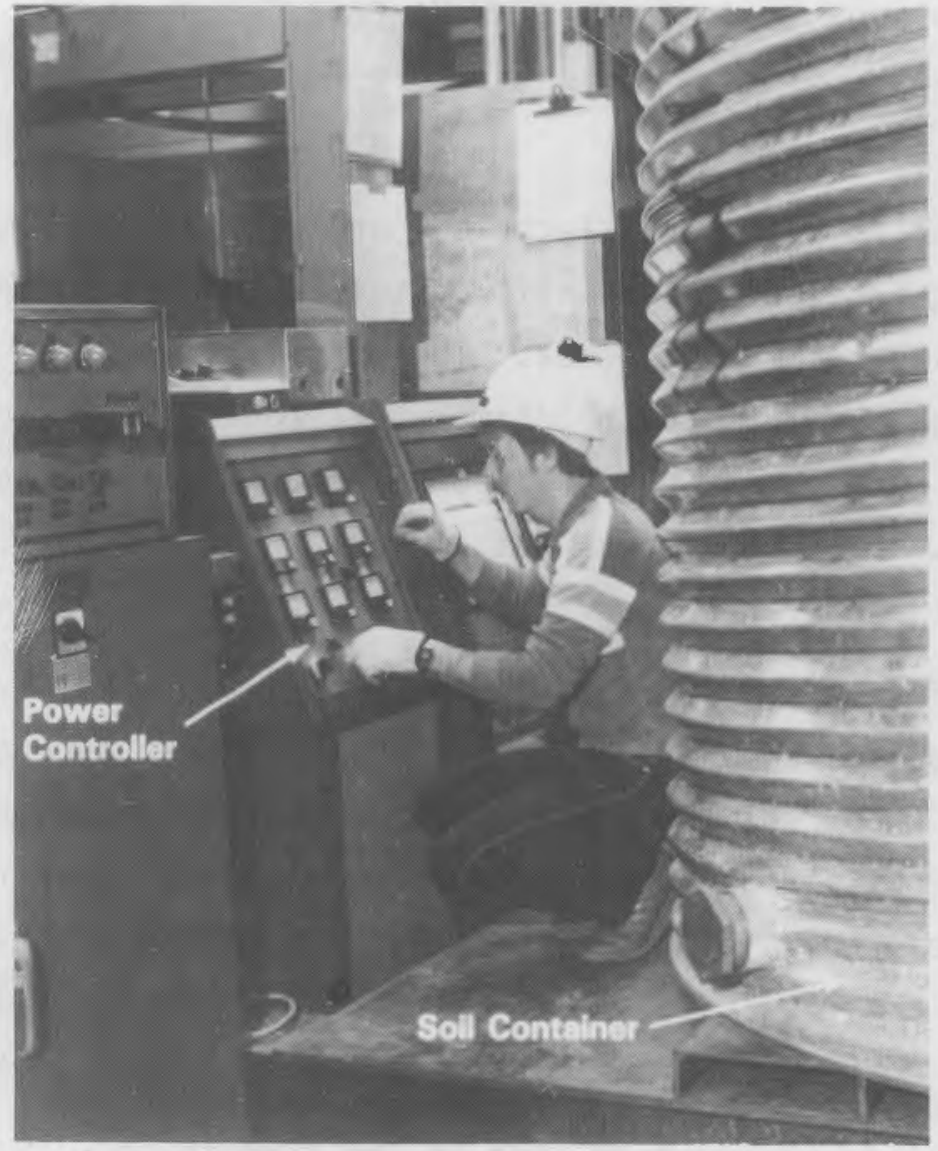

FIGURE 3. Engineering-Scale In Situ Vitrification 
DESCRIPTION OF SIMULATED WASTES

The simulated waste mixtures and volumes are shown in Table 1 . The simulated wastes were chosen according to the criteria established above. The top can contained a mixture of photographic developers and activator. Photographic wastes are generated chiefly by the Hanford Engineering Development Laboratory (HEDL), operated by Westinghouse, and by the Pacific Northwest Laboratory (PNL), operated by Battelle Memorial Institute. The second can was a mixture of aluminum, iron, and other nitrate and hydroxide salts in aqueous solution. This mixture is representative of many inorganic pilot plant, laboratory, and operations wastes generated at Hanford. The third an contained a $50 \%$ ethylene glycol/50\% water mixture simulating the spent antifreeze generated by all Hanford contractors. The bottom can contained a mixture of methylethyl ketone (MEK), Stoddard solvent, and enamel paint. This mixture simulates the painting waste routinely generated by Kaiser Engineers (KEH). It is also representative of other flammable wastes generated at Hanford.

\section{TEST EQUIPMENT}

The engineering-scale ISV electrical and off-gas unit is located at PNL in the 324 Building EDL-102 and the soil container hood assembly is located outside the 324 Building high bay area. The vitrification takes place within a $2.4-\mathrm{m}(8-\mathrm{ft})$ high by $1.8-\mathrm{m}(6-\mathrm{ft})$ diameter corrugated container. The engineering-scale power supply consists of a 30-kW Scott-Tee-connected transformer and control systems. The transformer has 16 voltage taps and is wired for secondary control with saturable reactors.

A sample of each simulated waste was contained in a 1-L closed metal can and buried in soil as shown in Figure 4. With this arrangement, each can was separated by $10 \mathrm{~cm}$ of soil, which allowed for differentiation between the simulated wastes in the off-gas sampling. Four molybdenum electrodes $1.9 \mathrm{~cm}(0.75$ inches) in diameter with $6.4-\mathrm{cm}(2.5-$ inch) graphite collars were inserted around the simulated waste cans on $30-\mathrm{cm}$ diagonal centers. The molybdenum electrodes were coated with fused $\mathrm{MoSi}_{2}$ for oxidation protection.

Type $K$ thermocouples were placed in the zone to be vitrified at $15-\mathrm{cm}$ intervals to a depth of $1.2 \mathrm{~m}$ to monitor the progress of the melt zone. An 
TABLE 1. Simulated Hanford Wastes

\begin{tabular}{|c|c|c|c|c|c|}
\hline & Naste & Major Components & Amount & Generator & $\begin{array}{l}\text { Total } \\
\text { Volume } \\
\end{array}$ \\
\hline Photo & Chemicals & $\begin{array}{l}\mathrm{Na}_{2} \mathrm{SO}_{3} \text { and } \mathrm{K}_{2} \mathrm{SO}_{3} \\
\mathrm{Na}_{2} \mathrm{CO}_{3} \text { and } \mathrm{K}_{2} \mathrm{CO}_{3} \\
\text { hydroquinone } \\
\mathrm{KOH} \\
\text { sodium formaldehyde } \\
\text { bisulfate } \\
\text { water }\end{array}$ & $\begin{array}{r}81.4 \mathrm{~g} / \mathrm{L} \\
9.1 \mathrm{~g} / \mathrm{L} \\
14.3 \mathrm{~g} / \mathrm{L} \\
17.3 \mathrm{~g} / \mathrm{L} \\
3.7 \mathrm{~g} / \mathrm{L} \\
\text { balance }\end{array}$ & HEDL, PNL & $750 \mathrm{~mL}$ \\
\hline $\begin{array}{l}\text { Pilot } \\
\text { Chemic }\end{array}$ & $\begin{array}{l}\text { Plant } \\
\text { cals }\end{array}$ & $\begin{array}{l}\mathrm{Al}\left(\mathrm{NO}_{3}\right)_{3} \cdot 9 \mathrm{H}_{2} \mathrm{O} \\
\mathrm{Fe}\left(\mathrm{NO}_{3}\right)_{3} \cdot 9 \mathrm{H}_{2} \mathrm{O} \\
\mathrm{Fe}\left(\mathrm{SO}_{4}\right)_{3} \cdot 9 \mathrm{H}_{2} \mathrm{O} \\
\mathrm{NaNO}{ }_{3} \\
\mathrm{Cr}\left(\mathrm{NO}_{3}\right)_{3} \cdot 9 \mathrm{H}_{2} \mathrm{O} \\
\mathrm{Cu}\left(\mathrm{NO}_{3}\right)_{3} \cdot 3 \mathrm{H}_{2} \mathrm{O} \\
\mathrm{Ca}\left(\mathrm{NO}_{3}\right)_{2} \\
\mathrm{Ni}\left(\mathrm{NO}_{3}\right)_{2} \cdot 6 \mathrm{H}_{2} \mathrm{O} \\
\mathrm{Zr}\left(\mathrm{NO}_{3}\right)_{4} \cdot 5 \mathrm{H}_{2} \mathrm{O} \\
\mathrm{HNO} \mathrm{H}_{3} \\
\mathrm{H}_{2} \mathrm{SO}_{4} \\
\mathrm{HF} \\
\mathrm{SiO} \\
\mathrm{NaOH} \text { (insoluble) }\end{array}$ & $\begin{array}{c}330.11 \mathrm{~g} / \mathrm{L} \\
42.02 \mathrm{~g} / \mathrm{L} \\
31.47 \mathrm{~g} / \mathrm{L} \\
18.7 \mathrm{~g} / \mathrm{L} \\
6.40 \mathrm{~g} / \mathrm{L} \\
0.43 \mathrm{~g} / \mathrm{L} \\
0.20 \mathrm{~g} / \mathrm{L} \\
2.47 \mathrm{~g} / \mathrm{L} \\
3.01 \mathrm{~g} / \mathrm{L} \\
41.12 \mathrm{~g} / \mathrm{L} \\
16.57 \mathrm{~g} / \mathrm{L} \\
4.13 \mathrm{~g} / \mathrm{L} \\
0.66 \mathrm{~g} / \mathrm{L} \\
0.6 \mathrm{~L} \mathrm{of} \\
19 \mathrm{M} \mathrm{NaOH} / \mathrm{L}\end{array}$ & PNL, RHO & $750 \mathrm{~mL}$ \\
\hline it ifreez & & $\begin{array}{l}\text { ethylene glycol } \\
\text { water }\end{array}$ & $\begin{array}{l}50 \% \\
50 \%\end{array}$ & $\begin{array}{l}\text { all } \\
\text { contractors }\end{array}$ & $325 \mathrm{~mL}$ \\
\hline ainting & Waste & $\begin{array}{l}\text { methylethyl ketone } \\
\text { Stoddard solvent } \\
\text { enamel paint }\end{array}$ & $\begin{array}{r}98 \% \\
1 \% \\
1 \%\end{array}$ & KEH & $125 \mathrm{~mL}$ \\
\hline
\end{tabular}




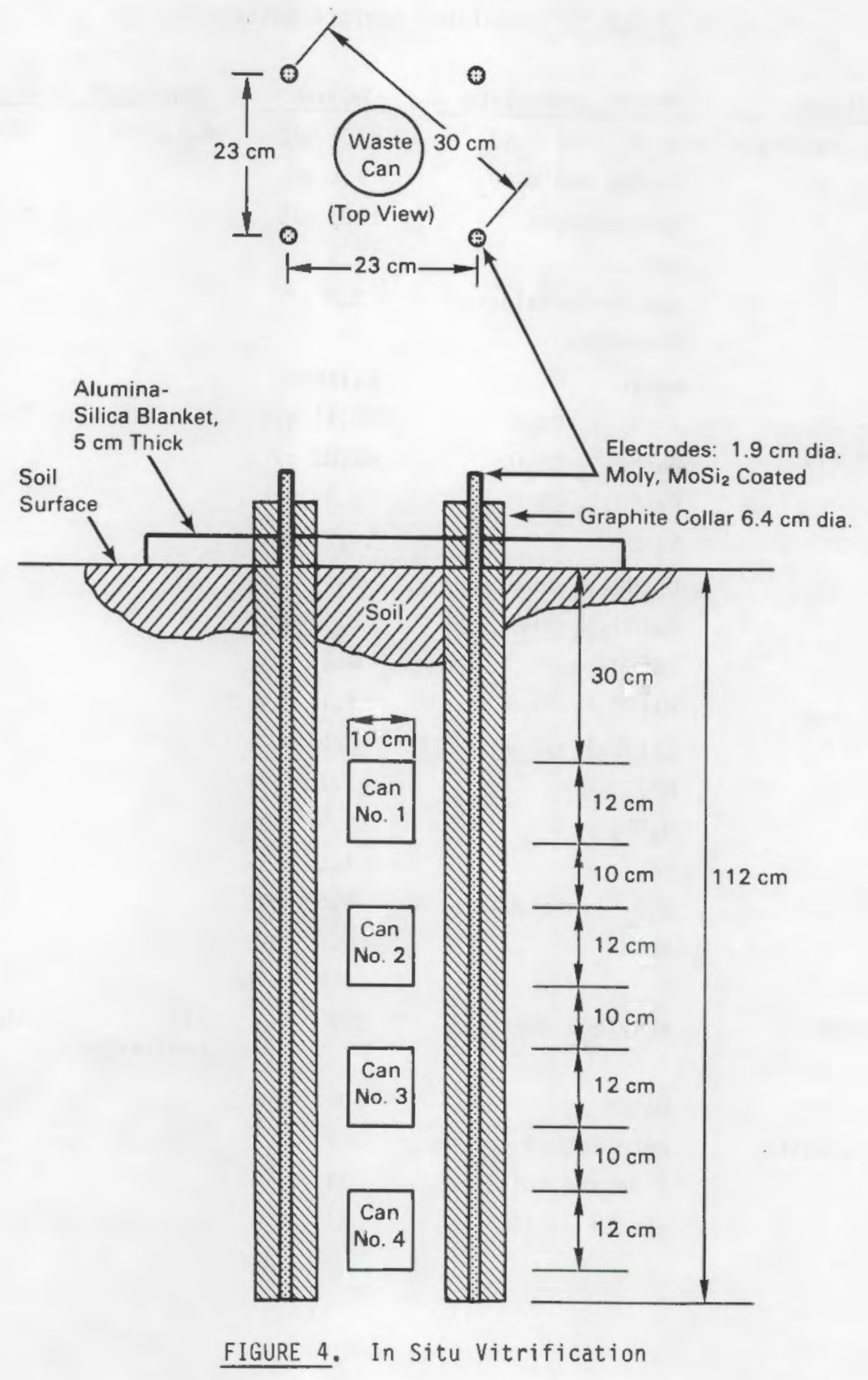


additional thermocouple was placed directly under each simulated waste can. The thermocouples were placed horizontally into the melt zone with the connecting ends running vertically along the sides of the soil container for connection at the surface. Two thermocouples and a pressure tap were also inserted into each can. The can pressures were monitored using a Bourdon tube pressure gage and recorded by a video camera. The temperature of the plenum above the melt was also monitored.

The surface of the zone to be vitrified was covered with $5 \mathrm{~cm}$ of aluminasilica insulating blanket, leaving a $1-\mathrm{cm}$ gap between each electrode and the insulation for venting. The insulation helps promote subsidence of the molten surface and improve the efficiency of the melting operation.

\section{OFF-GAS MEASUREMENTS}

Off gas from the vitrification zone was sampled continuously with an isokinetic sample system to obtain a representative sample of the off-gas constituents. The off gas was drawn through two $1-\mathrm{cm}(3 / 8-i n c h$ OD) stainless steel sample tubes for different analyses. One leg of the sample system was connected to two 500-mi water bubblers, a millipore filter, a desiccant bottle, an air sample pump, and a wet test meter as shown in Figure 5 . Samples of the bubbler solutions were analyzed using induction coupled plasma (ICP) to determine the metal and cation levels of the off-gas particulates.

The second leg of the off-gas sample system was used to determine destruction efficiencies for specific chemicals in each waste container. A different sampling train was set up to sample the desired off-gas constituents for each can. The Hanford Environmental Health Foundation (HEHF) determined the sampling procedure to be consistent with EPA/NIOSH (National Institute of Safety and Health) methods and analyzed the off-gas samples for each can. A summary of the off-gas sampling for each can is shown in Table 2. 


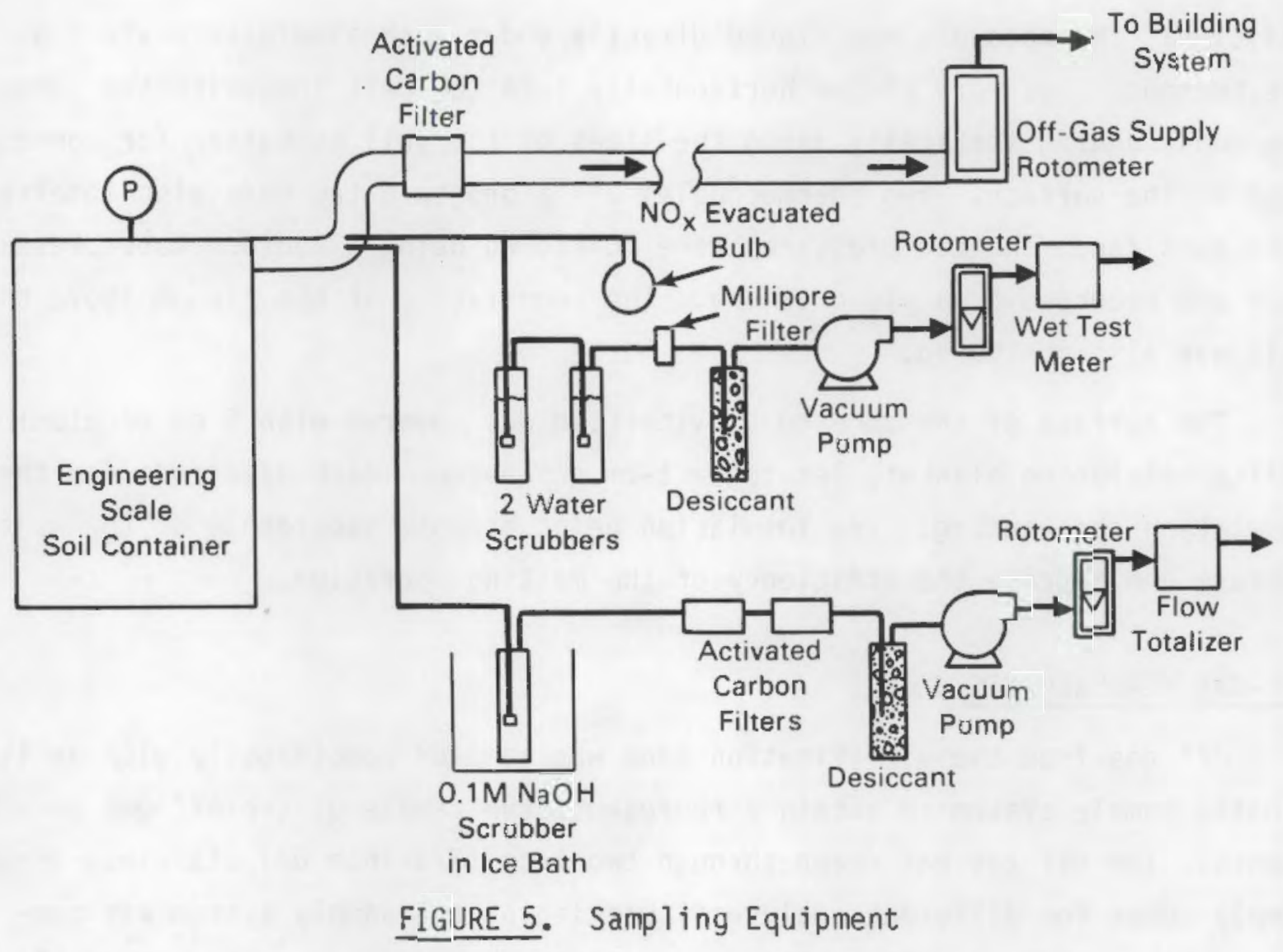

TABLE 2. Off-Gas Sampling Details

\begin{tabular}{|c|c|c|c|}
\hline Can & Contents & Chemicals Analyzed & Analytical Method \\
\hline 1 & photographic chemicals & $\begin{array}{l}\mathrm{SO}_{2} \\
\text { formaldehyde }\end{array}$ & $\begin{array}{l}40 \text { CFR } 60 \text {, method } 6 \\
\text { NIOSH, method } 3500\end{array}$ \\
\hline 2 & hydroxides and nitrates & ${ }^{\mathrm{N}} \mathrm{x}_{\mathrm{x}}$ & 40 CFR 60 , method $7 \mathrm{~A}$ \\
\hline 3 & antifreeze & ethylene glycol & NIOSH method P\&CM 338 \\
\hline 4 & painting chemicals & methylethyl ketone & NIOSH method 2500 \\
\hline
\end{tabular}




\section{EXPERIMENTAL RESULTS}

The Hanford hazardous waste engineering-scale experiment was completed in September 1986. The test took 23 hours to melt through the four cans to a depth of $1.2 \mathrm{~m}$, as indicated by thermocouple temperatures. The operational performance of the equipment was very good, with the exception of a temperature recorder malfunction between 13.72 and 15.42 hours after start up, which resulted in the loss of some temperature data.

Because of the $4-\mathrm{cm}$ physical separation of the waste containers in the soil, the experiment can be treated as a series of four independent tests. The off-gas results and can contents release data will be presented in four sections, one for each can of simulated waste which will be discussed in later sections. The contents release data, which tell the time, temperature, and rate at which can contents were evaporated or immobilized, are important for scale up of the off-gas treatment system. Off-gas and soil analyses were used to determine efficiencies for the destruction of selected chemicals in the simulated waste.

\section{RELEASE OF CAN CONTENTS}

The rate at which the waste container released its contents is important to the design of large scale experiments. If the release rate is too high, combustion of the container contents may raise the hood temperature above design limits or exceed the off-gas treatment equipment capacity. The heat-up of the can, breachment of the can by the molten glass, and volatilization of the can's contents were monitored by two thermocouples placed in the can and by the pressure in the can. One thermocouple was placed at the bottom of the can to measure liquid temperature and another was inserted into the upper region of the can to monitor the can plenum temperature. The rate of release of can contents and the heat generated by combustion is shown in Table 3 for each can.

The contents release time for each can included the period from breachment of the can by molten glass (when the upper can temperature went off scale) to the time the can bottom temperature went off scale. In most cases, the can pressure dropped sharply when the upper can temperature rapidly increased, 
TABLE 3. Can Contents Release Data

\begin{tabular}{|c|c|c|c|c|c|c|}
\hline Can & Contents & $\begin{array}{l}\text { Liquid } \\
\text { Volume } \\
\text { (mL) }\end{array}$ & $\begin{array}{l}\text { Heat of } \\
\text { Combustion } \\
\text { (kcal) }\end{array}$ & $\begin{array}{l}\text { Release } \\
\text { Time } \\
\text { (min) }\end{array}$ & $\begin{array}{c}\text { Liquid } \\
\text { Rate } \\
(\mathrm{mL} / \mathrm{min})\end{array}$ & $\begin{array}{c}\text { Vapor } \\
\text { Rate } \\
\text { (std } L / m \text { ) }\end{array}$ \\
\hline 1 & photographic chemicals & 750 & 0 & $>13$ & - & -- \\
\hline 2 & pilot plant chemicals & 750 & 0 & 43 & 17 & 21 \\
\hline 3 & antifreeze & 325 & 815 & 86 & 4 & 3.1 \\
\hline 4 & painting chemicals & 125 & 1638 & 38 & 3 & 0.8 \\
\hline
\end{tabular}

indicating the loss of can integrity. The pressure dropped from off scale, greater than $17 \mathrm{psig}$ or $120 \mathrm{kilo}$ Pascals gage ( $\mathrm{kPag}$ ), to zero in less than two seconds when each can de-pressurized. The pressure curves for can 2 and can 3 showed a momentary pressure decrease followed by a pressure increase just before the pressure went to zero, indicating that the can was temporarily resealed by molten glass after its initial loss of integrity.

Release Data for Can 1: Photographic Chemicals

As shown in Figure 6 , the upper and lower in-can temperatures showed a marked increase about 2.25 hours after startup, followed by steady increase to about $200^{\circ} \mathrm{C}$ at 3.38 hours ( 68 minutes), after which the temperature went of $f$ scale. The molten glass breached the can shortly after 3.38 hours, as indicated by can temperatures over $1000^{\circ} \mathrm{C}$. The can pressure stayed at $0 \mathrm{kPag}$ the entire time, suggesting that the can may have leaked and released its volatile contents slowly before being breached by the molten glass. This hypothesis is substantiated by the fact that the lower can temperature went off scale less than 3 minutes after the upper temperature, indicating that little liquid was left in the bottom of the can to vaporize.

Release Data for Can 2: Pilot Plant Chemicals

Figure 7 shows that the can temperatures started to increase at 3.95 hours after start-up. The upper can thermocouple reached $200^{\circ} \mathrm{C}$ at 4 hours and the lower thermocouple reached $200^{\circ} \mathrm{C}$ at 6.88 hours. The molten glass breached the can shortly after 6.17 hours and vaporized the can contents (750 mL of aluminum-iron nitrates and hydroxides) in the 43-minute period between 6.17 and 6.88 hours. 

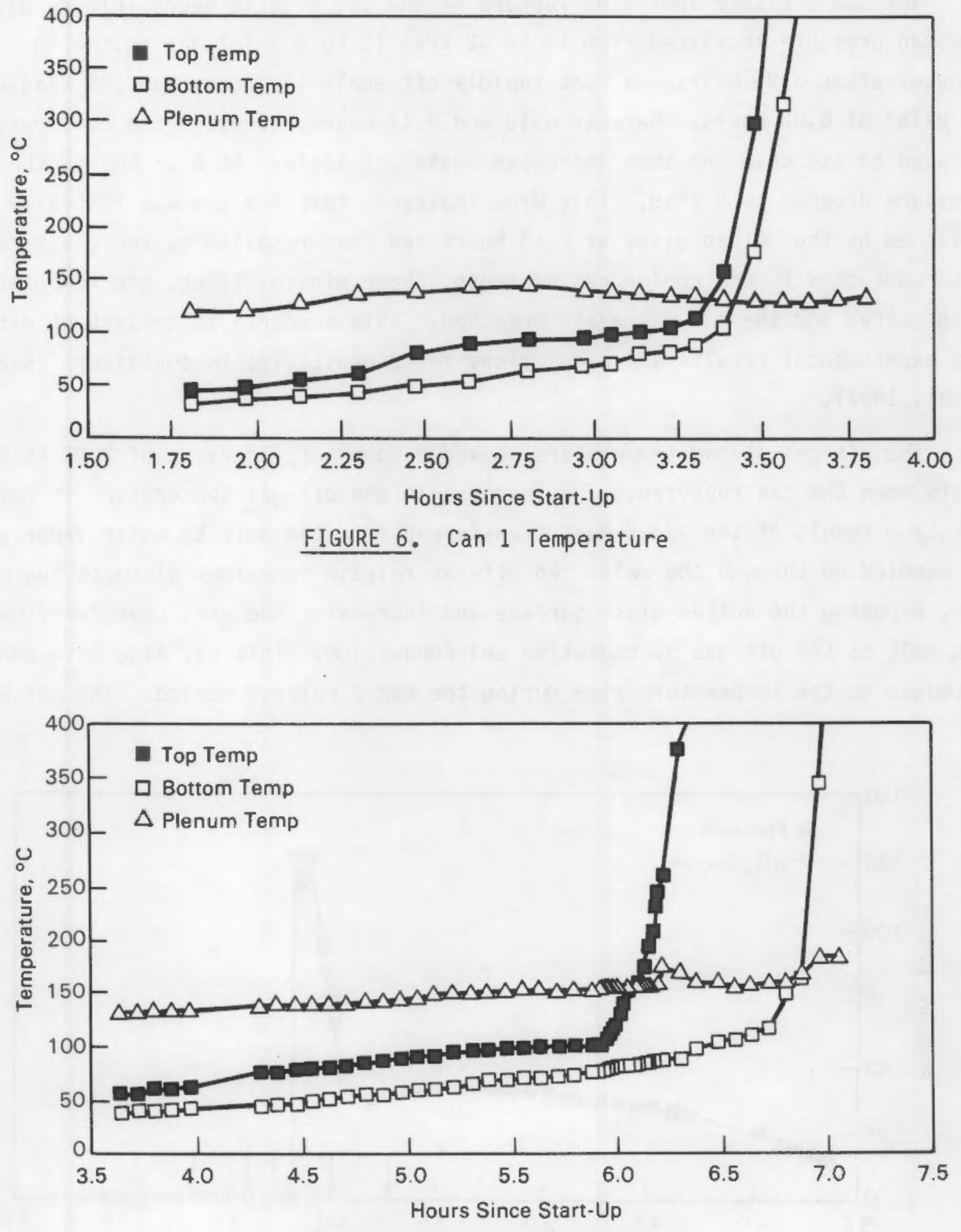

FIGURE 7. Can 2 Temperatures 
The can pressure indicated rupture of the can at 6.18 hours (Figure 8 ). The can pressure increased from 14 to $42 \mathrm{kPag}$ ( 2 to $6 \mathrm{psig}$ ) during the 50 minutes after 3.95 hours and went rapidly off scale (greater than $120 \mathrm{kPag}$ or 17 psig) at 6.08 hours. Between 6.10 and 6.17 hours, however, the can pressure dropped to $114 \mathrm{kPag}$ and then increased again off scale. At 6.18 hours, the pressure dropped to $0 \mathrm{kPag}$. This drop indicates that the can was initially breached by the molten glass at 6.10 hours and then resealed as the glass came into contact with the cooler can contents. Four minutes later, the temporary plug melted and the can was again breached. This scenario is consistent with the experimental results and predictions for combustibles in containers (Buelt et al. 1987).

The off-gas plenum temperature showed a momentary increase of $20^{\circ} \mathrm{C}$ at 6.17 hours when the can ruptured. The increase in the off-gas temperature is most likely a result of the added heat transferred from the melt to water vapor as it bubbled up through the melt. An off-gas release sometimes disrupts the cold cap, exposing the molten glass surface and increasing the heat transfer from the melt to the off gas by radiation and conduction. This may also have contributed to the temperature rise during the can 2 release period. The can 2

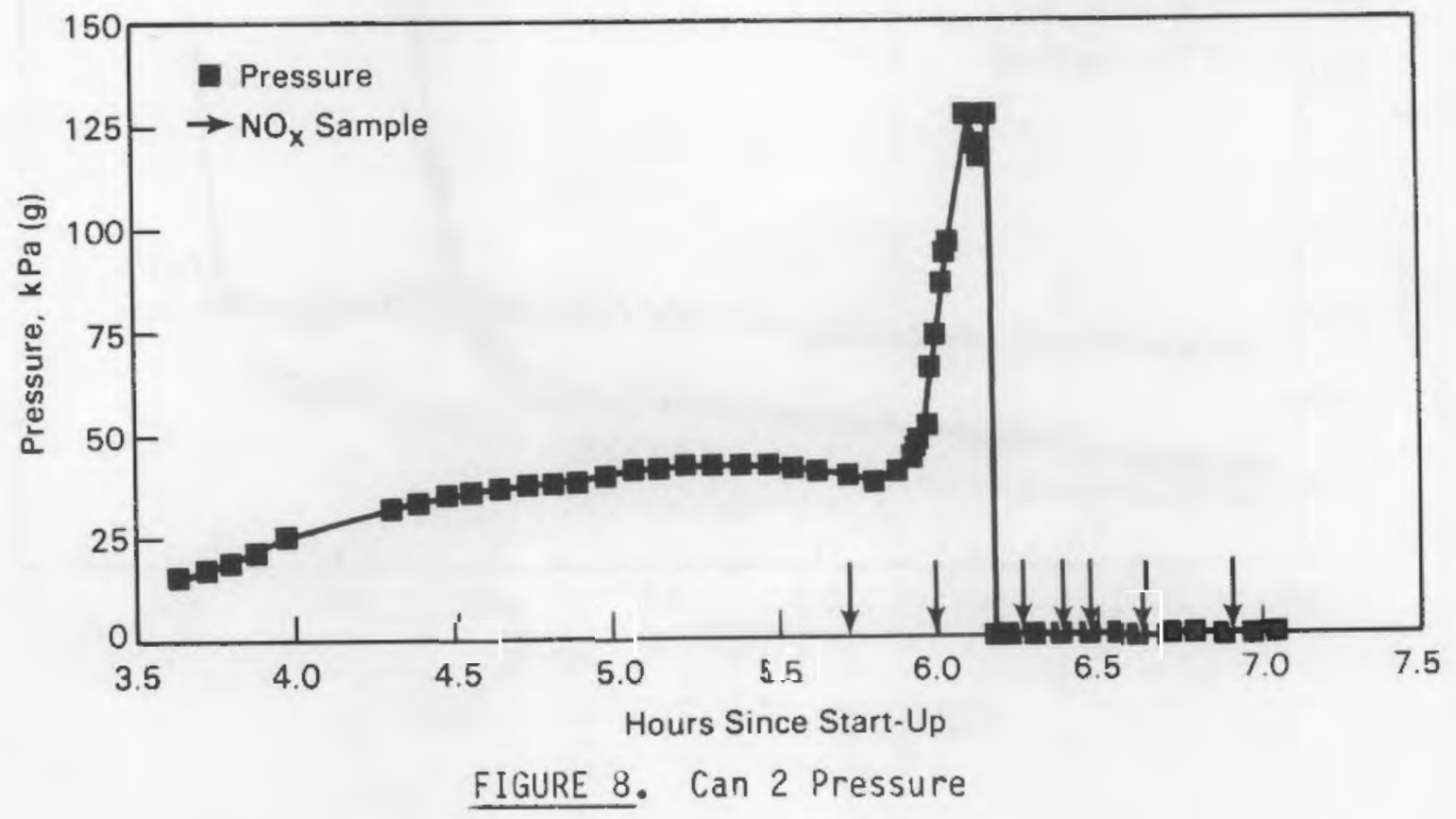


vapor release rate of 21 std. L/min was much greater than the release rates from cans 3 and 4 (Table 3 ), so the plenum temperature increase was sharper for can 2.

\section{Release Data for Can 3: Antifreeze Solution}

Figure 9 shows that the can temperatures started to increase at about 8 hours after start-up. The upper can thermocouple reached $200^{\circ} \mathrm{C}$ at 10.7 hours and the lower thermocouple reached $200^{\circ} \mathrm{C}$ at 11.97 hours. The molten glass breached the can shortly after 10.7 hours. Approximately 86 minutes were required to vaporize the can contents (325 $\mathrm{ml}$ of $50 / 50$ ethylene glycol and water).

The can pressure, as shown in Figure 10, went from 0 to over $120 \mathrm{kPag}$ (17 psig) between 10.12 and 10.88 hours after start-up. The can pressure curve showed a double release of can pressure, one at 10.88 hours and another at 11.07 hours, coinciding with the upper temperature increase. As with can 2, the molten glass probably formed a temporary plug that subsequently melted and resulted in two pressure releases for the can. The off-gas plenum temperature showed a gradual increase in temperature of $20^{\circ} \mathrm{C}$ over the release period, but no sharp change as seen with can 2.

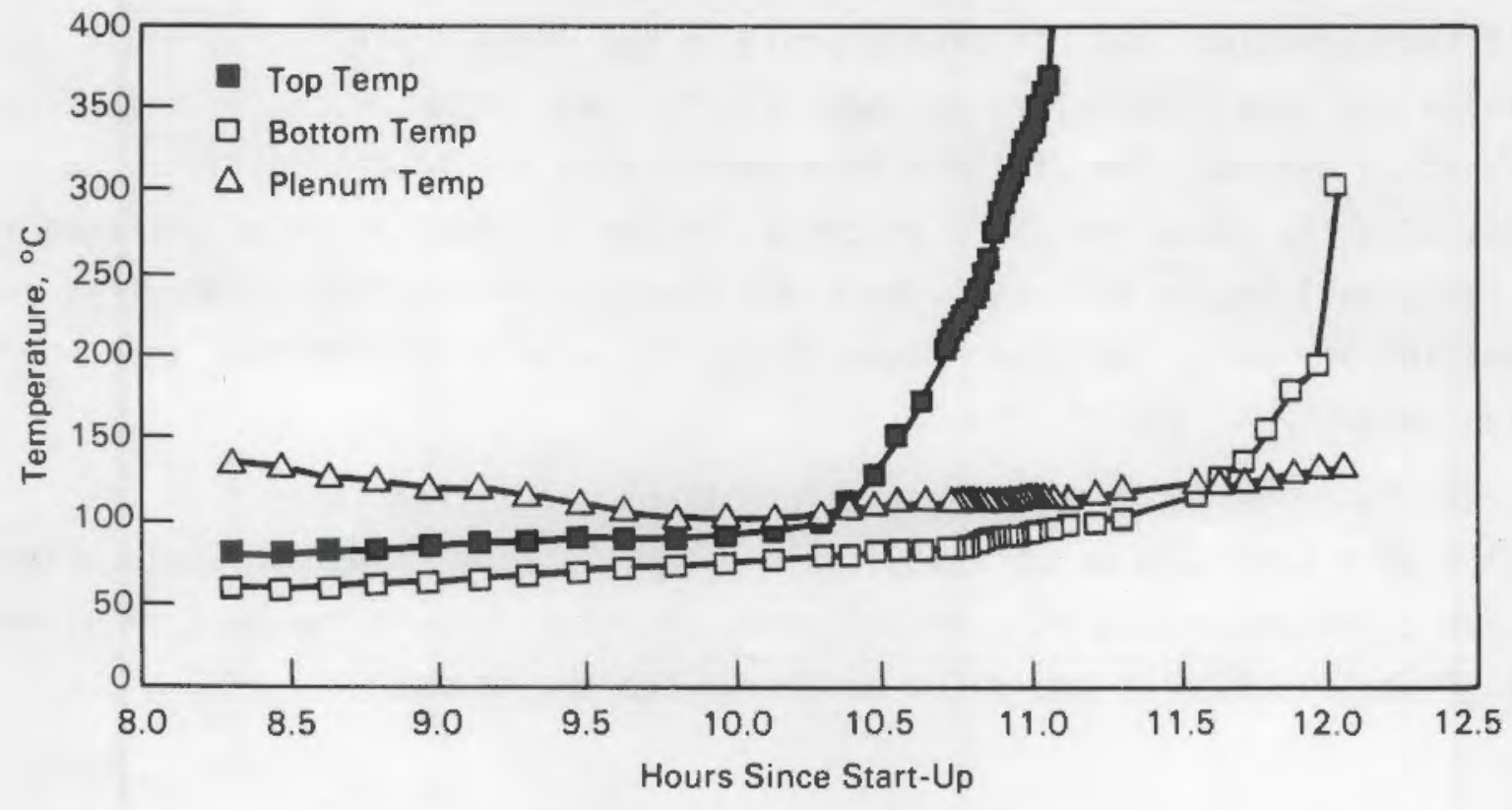

FIGURE 9. Can 3 Temperatures 


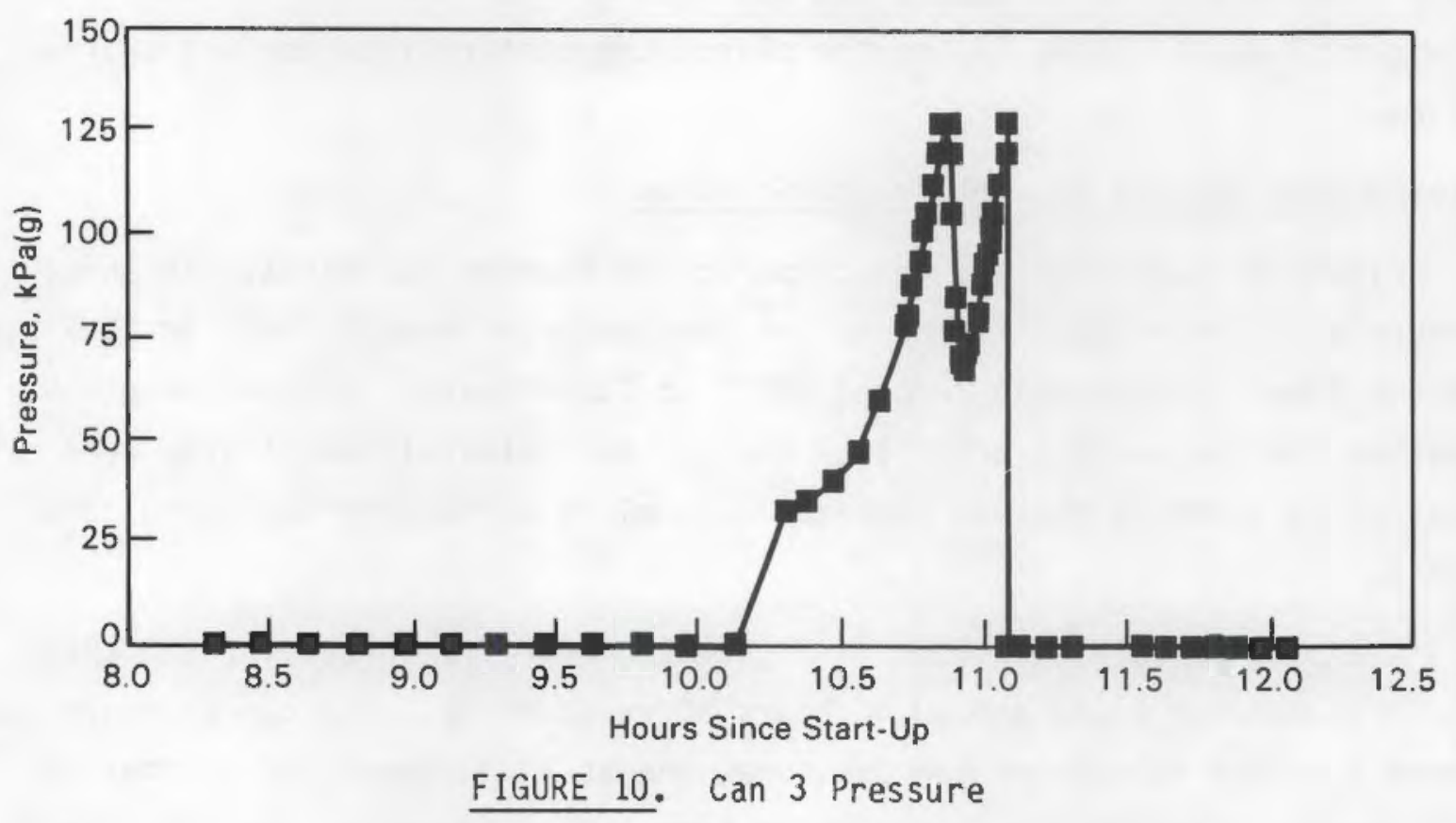

The heating value of the ethylene glycol vaporized during the destruction of can 3 was $1640 \mathrm{kcal}$. As shown in Figure 9, the of $\mathrm{f}$-gas temperature rose about $20^{\circ} \mathrm{C}$ over the 86 -minute release time. This temperature rise is in rough agreement with the $15^{\circ} \mathrm{C}$ temperature increase predicted by heat transfer calculations. Calculations indicate that a 40-minute release of a 55-gallon drum of antifreeze solution ( $50 \%$ ethylene glycol) in the large-scale system would increase the hood temperature to about $290^{\circ} \mathrm{C}$. Four drums processed simultaneously at an of $\mathrm{f}$-gas flow of $100 \mathrm{~m}^{3} / \mathrm{min}$ would raise the hood temperature to $765^{\circ} \mathrm{C}$, slightly above the $750^{\circ} \mathrm{C}$ criteria for the off-gas system established in the Functional Design Criteria (Buelt and Carter 1986a). The air required for combustion of four drums of ethylene glycol is $50 \mathrm{~m}^{3} / \mathrm{min}$, much less than the design capacity of $100 \mathrm{~m}^{3} / \mathrm{min}$.

It should be noted that these calculations are extrapolated from the results of a small volume of combustible material. The effect of scale on both the can contents release rate and the heat transfer rate to the hood requires further verification on the pilot and large-scale systems. 


\section{Release Data for Can 4: Paint Shop Chemicals}

Figures 11 and 12 show the can pressure and temperatures during the heating and rupture of can 4 . Although the temperature data logger malfunctioned during the destruction of the paint shop chemicals, the release time can be estimated from two temperatures taken manually. The can 4 pressure gage was over-ranged at 13.38 hours after startup when pressure recording began, and dropped to 0 at 15.42 hours, indicating a release of the can pressure. The can temperature data show the major release estimated from two temperatures taken manually. The can 4 pressure gage was over-ranged at 13.38 hours after startup when pressure recording began, and dropped to 0 at 15.42 hours, indicating a release of the can pressure. The can temperature data show the major release of can contents between 17.0 and 17.63 hours, but some of the MEK may have already boiled of through the can rupture starting at 15.42 hours when the can pressure was released.

The hood off-gas temperature was calculated to increase $32^{\circ} \mathrm{C}$ while the simulated painting waste was being incinerated, due to the heat of combustion of the MEK over the 38 -minute release time. The temperature decreased by $38^{\circ} \mathrm{C}$ soon after the MEK had evaporated and been incinerated (as indicated by the can's lower temperature). The heat of combustion of MEK is about twice that of ethylene glycol. Calculations indicate that the destruction of a 55-gallon drum of MEK over a period of 40 minutes would increase the large-scale ISV offgas hood temperature to about $550^{\circ} \mathrm{C}$. The air required for combustion would be 34 std. $m^{3} / m i n$. Two drums destroyed simultaneously would raise the hood temperature to about $930^{\circ} \mathrm{C}$, well over the hood design specification. As with the ethylene glycol calculations, additional pilot and large-scale tests are required to verify ISV for the destruction of large quantities of MEK.

\section{OFF-GAS ANALYSES}

The off gas was sampled for inorganic particulates during the destruction of each of the four simulated waste containers. In addition, specific analyses of the off gas were used to determine the destruction or retention of certain major chemicals from each can. 


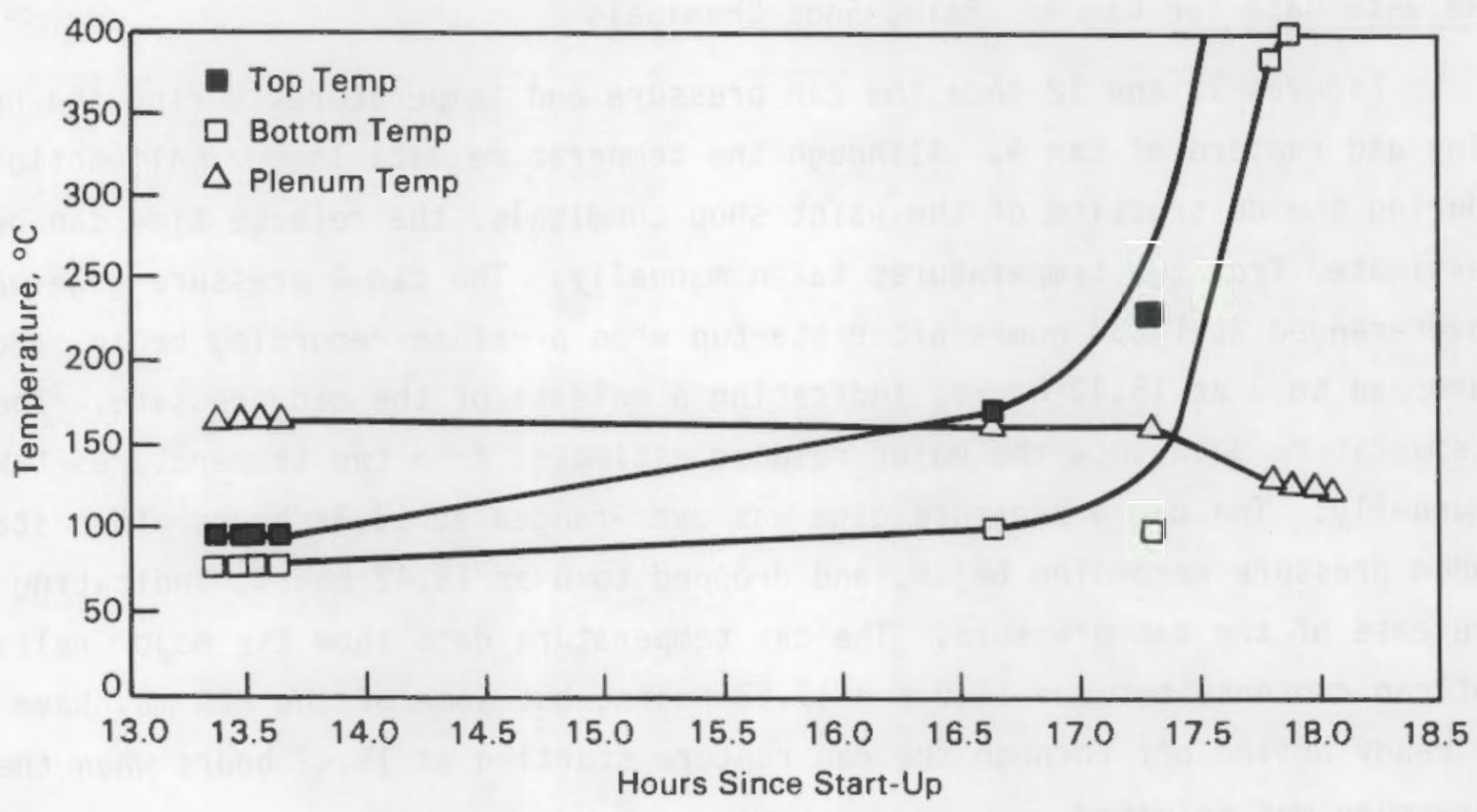

FIGURE 11. Can 4 Temperatures

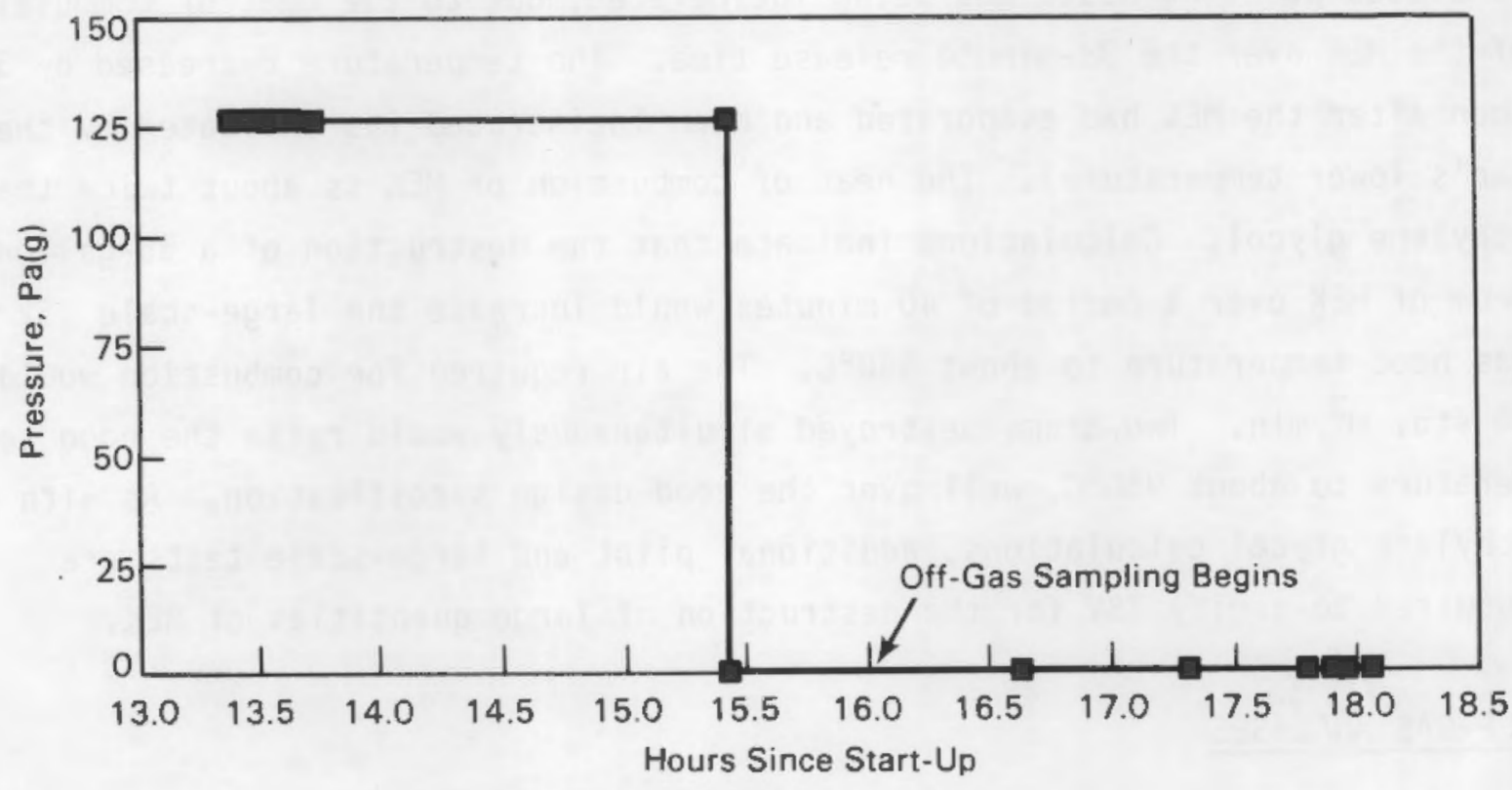

FIGURE 12. Can 4 Pressure 
The off gas was sampled for inorganic particulates using 500-mL water bubblers. The results of ICP analyses for selected metal particulates in this bubbler solution are given in Table 4. These analyses show higher levels of aluminum, calcium, copper, and sodium during the destruction of can 2, which contained the simulated pilot plant waste. These were major components in the pilot plant waste solution. Other cation levels in the impinger solutions varied between cans but were lowest in the can 1 impinger solution. Chrome, nickel, and iron were the highest in the can 3 impinger solution. These metals are found naturally in the soil and in the metal cans and are carried by the off gas in small quantities as a normal consequence of ISV operation.

TABLE 4. Analysis of Impinger Solutions

Contents

Sample Time $(h)$

Al (ppm)

Ca $(p p m)$

$\mathrm{Cu}(\mathrm{ppm})$

$\mathrm{Cr}(\mathrm{ppm})$

$\mathrm{Fe}(\mathrm{ppm})$

$K$ (ppm)

Mn (ppm)

Mo (ppm)

$\mathrm{Na}$ (ppm)

$\mathrm{Ni}$ (ppm)

$\mathrm{Si}$ (ppm)

Zn (ppm)

$\frac{\text { Can } 1}{\text { photo chem }}$

$$
2.08
$$

$<0.03$

0.031

0.007

$<0.02$

$<0.005$

$<0.3$

0.014

0.394

0.605

$<0.02$

0.104

1.89

$\frac{\text { Can } 2}{p \cdot p \cdot \text { chem }}$

4.10

1.44

0.482

0.442

3.17

12.3

5.8

0.318

7.01

75.0

1.71

3.98

9.33

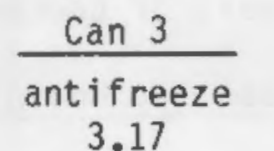

$\frac{\text { Can } 4}{\text { paint chem }}$

0.161

0.080

0.029

5.24

21.1

0.7

0.564

0.589

5.17

3.4

1.23

10.7
0.190

0.071

0.024

2.04

11.7

$<0.3$

0.322

0.312

1.5

1.91

3.61

3.61 
The off gas was analyzed by HEHF for specific chemicals from the simulated waste, and concentrations were reported in parts per million (ppm) or $\mathrm{mg} / \mathrm{m}^{3}$ based on sample analyses and sample volumes. Continuous samples were collected over the entire sampling period for all species except the NO$_{x}$, which was grab sampled at specific times. The results showed acceptable decontamination factors (DFs) for the major chemicals in the simulated wastes. The efficiency of retaining or destroying hazardous chemicals can be expressed as DF. It is defined as:

$$
D F=\frac{m_{i}}{m_{e}}
$$

where $\mathrm{mi}=$ initial mass of contaminant in the control volume per time me $=$ exit mass of contaminant in the control volume per time.

Off-Gas Analyses Can 1: Photographic Chemicals

The off gas was sampled continuously for formaldehyde and $\mathrm{SO}_{2}$ between 1.88 and 3.97 hours after startup. During the sample period, can 1 temperatures went from $40^{\circ} \mathrm{C}$ to greater than $1000^{\circ} \mathrm{C}$. The average off-gas $\mathrm{SO}_{2}$ concentration for this sampling period was $7.6 \mathrm{ppm}$ or $20 \mathrm{mg} / \mathrm{m}^{3}$. This yields a DF of 30 for sulfates in the waste, assuming all volatile sulfur in the off gas was converted to $\mathrm{SO}_{2}$. Sulfates are relatively insoluble in the molten glass and much of the sulfate may have been in the form of $\mathrm{SO}_{3}$, which was not measured. However, an additional $\mathrm{SO}_{2}$ DF of 1000 can be expected in the ISV off-gas system before the off gas is exhausted to the atmosphere (Buelt and Carter 1986), which brings the release below acceptable environmental release standards for $\mathrm{SO}_{\mathrm{x}}$.

The average formaldehyde concentration in the off gas over the sampling period was $0.019 \mathrm{mg} / \mathrm{m}_{3}$. This is a destruction efficiency of $99.8 \%(D F=530)$. For comparison, Timmerman (1986) measured an ISV destruction efficiency of 99.95\% (DF $=2000)$ for polychlorinated biphenyls (PCBs). An additional 99\% removal efficiency can be expected in the off-gas scrubbing system, which brings the overall formaldehyde destruction and removal efficiency to $99.998 \%$; this removal efficiency is greater than required by federal regulations (40 CFR 264.343) for incineration of hazardous wastes. 
Off-Gas Analyses Can 2: Pilot Plant Chemicals

Eight $\mathrm{NO}_{\mathrm{x}}$ off-gas grab samples were taken between 5.47 and 6.80 hours after startup. Sample times are shown in Figure 6. The samples were collected in evacuated flasks containing a dilute sulfuric acid-hydrogen peroxide absorbing solution. The nitrogen oxides, except nitrous oxide, were oxidized to nitrate and analyzed by ion chromatography. All eight samples gave $\mathrm{NO}_{\mathrm{x}}$ concentrations of less than the detection limit of $40 \mathrm{ppm}$ or $80 \mathrm{mg} / \mathrm{m}^{3}$. This indicates a nitrate destruction efficiency of at least $96 \%$ (DF>28) for the experiment. The batch technique used for the $\mathrm{NO}_{x}$ analyses is less sensitive than the continuous analysis used in the large-scale ISV tests. Previous experience (Buelt and Carter 1986) has demonstrated ISV destruction efficiencies of greater than $99.6 \%$ (DF > 250) for nitrates.

\section{Off-Gas Analyses Can 3: Antifreeze Solution}

A continuous sample of the off gas was taken between 10.22 and 13.38 hours after startup and analyzed for ethylene glycol. The off-gas sampling was initiated as soon as the can 3 pressure started to increase. The ethylene glycol concentration was determined to be less than the detection 1 imit of $80 \mathrm{mg} / \mathrm{m}^{3}$. This concentration gives an ISV destruction efficiency of greater than 98\% (DF $>60)$ for ethylene glycol. As with the $\mathrm{N}_{x}$ analyses, the ethylene glycol was below the detection level of the analytical method. Even so, with an additional $99 \%$ removal efficiency in the off-gas scrub system, the overall destruction and removal efficiency is $>99.98 \%$, near the $99.99 \%$ required by federal regulations.

Dff-Gas Analyses Can 4: Paint Shop Chemicals

The off gas was sampled continuously for MEK between 16.13 and 23.13 hours after start-up. As shown in Figure 13, can 4 de-pressurized at 15.42 hours. Although the off-gas analysis for MEK indicated a concentration below the detection limit $\left(<0.3 \mathrm{ppm}\right.$ or $\left.0.9 \mathrm{mg} / \mathrm{m}^{3}\right)$, some release of the MEK may already have occurred before sampling was initiated. Assuming the bulk of the MEK was vaporized in the 38 minutes between 17.0 and 17.47 hours after startup, the MEK destruction efficiency was at least $99.98 \%$ (DF $>6900)$. However, the DF may 
- Sampled as shown at

- Face of partially vitrified zone

- $100^{\circ} \mathrm{C}$ isotherm $(23 \mathrm{~cm}$ from block)

- $25^{\circ} \mathrm{C}$ isotherm $(43 \mathrm{~cm}$ from block)

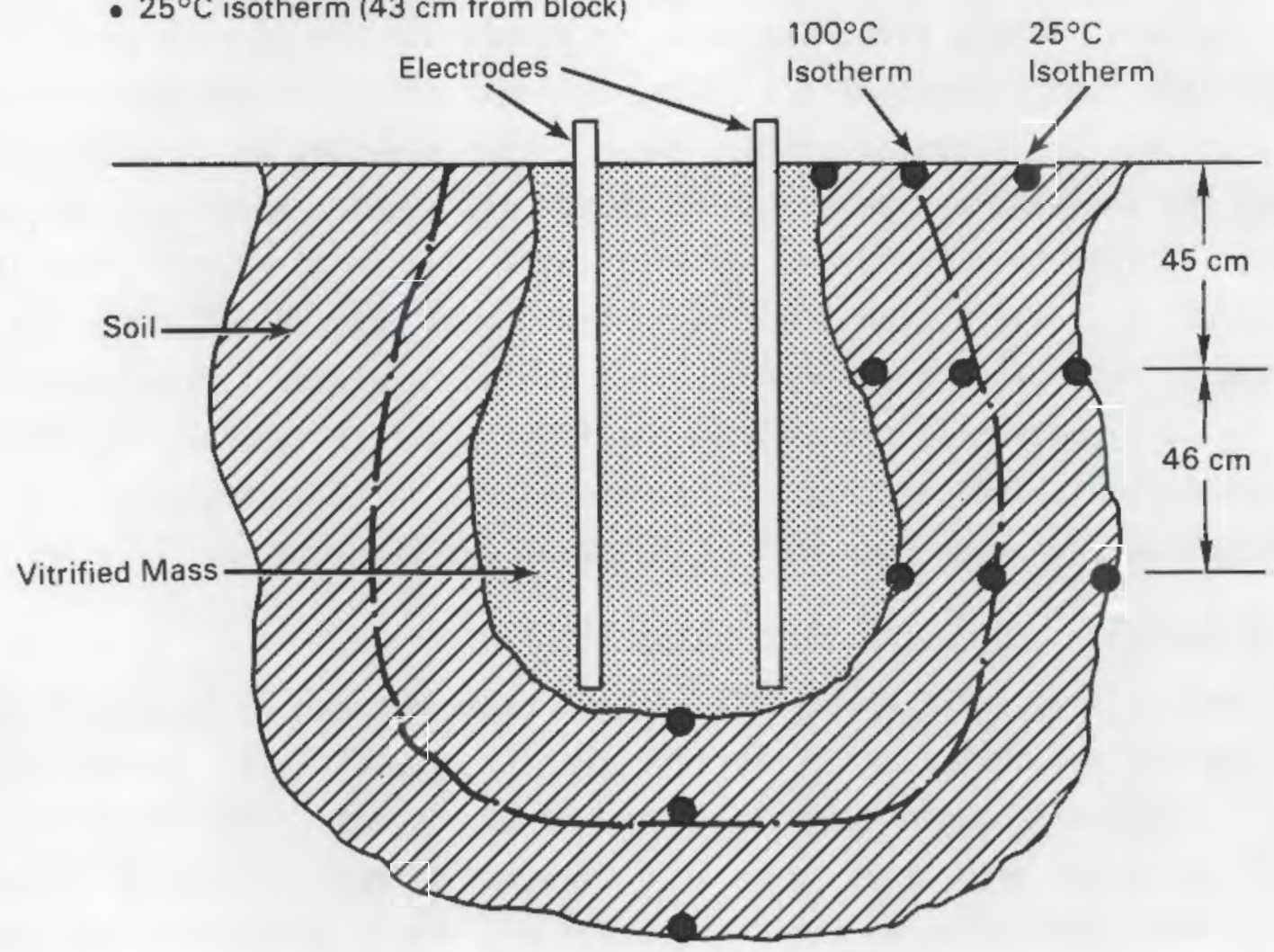

FIGURE 13. ISV Sample Locations

actually have been lower, depending on the amount of MEK that escaped from the can between the time it de-pressurized and when sampling was initiated.

\section{SOIL ANALYSES}

Some organic chemicals have a high mobility in soil and may actually evaporate and recondense ahead of the advancing molten glass. Low-boilingpoint chlorinated hydrocarbons such as carbon tetrachloride and trichloroethylene migrate into the surrounding soil away from the ISV block and may remain in the soil if they do not move upward. Other organics such as PCBs have a lower volatility and are absorbed by the soil. The less volatile organics are destroyed before they can be transported away from the molten glass. The use of containers decreases the possibility of organic chemical migration into the 
soil. In this experiment, the soil surrounding the ISV block was sampled and analyzed for total organic carbon (TOC) and for the major organic chemicals contained in the simulated wastes. Table 5 gives the analyses performed on the soil samples.

Figure 13 shows the soil sampling locations. Samples were taken adjacent to the vitrified block and at 23 and $43 \mathrm{~cm}$ from the block. The $100^{\circ} \mathrm{C}$-isotherm was $23 \mathrm{~cm}$ from the block; at $43 \mathrm{~cm}$ the temperature did not exceed $25^{\circ} \mathrm{C}$. Trace amounts of organics with boiling points of 80 to $100^{\circ} \mathrm{C}$ that migrate by vaporization or condensation may be present in the middle or outer soil samples.

As can be seen from Table 6 , the specific chemical analyses for ethylene glycol and hydroquinone are below detectable limits. Although specific chemical analyses are not available for the soil samples adjacent to the block, any volatile organics at this point will have been destroyed or driven outward to cooler soil. The TOC analyses support this supposition since the TOC, uniform at 0.9 to $1.0 \%$ in most other samples, was reduced to $0.6 \%$ in the nearblock samples, indicating considerable decomposition of the organics by heating.

\section{TABLE 5. Soil Sampling Details}

\begin{tabular}{|c|c|c|c|}
\hline Chemical Analyzed & Source & Analys is Method & Detection Limit \\
\hline total organic carbon & all & TOC, dry basis & -- \\
\hline formal dehyde & $\operatorname{can} 1$ & $\begin{array}{l}\text { Method T05, Compendium of } \\
\text { Methods for Determination of } \\
\text { Toxic Organic Compounds }\end{array}$ & $0.05 \mathrm{ppm}$ \\
\hline hydroquinone & can 1 & NIOSH, method S57 & $0.2 \mathrm{ppm}$ \\
\hline ethylene glycol & $\operatorname{can} 3$ & $\begin{array}{l}\text { Gas chromatography, flame } \\
\text { ionization detector }\end{array}$ & $1.0 \mathrm{ppm}$ \\
\hline methylethyl ketone & $\operatorname{can} 4$ & $\begin{array}{l}\text { Gas chromatography, flame } \\
\text { ionization detector }\end{array}$ & $1.0 \mathrm{ppm}$ \\
\hline
\end{tabular}

$\mathrm{NIOSH}=$ National Institute of Occupational Health and Safety. 
TABLE 6. Analyses of Soil Samples

\begin{tabular}{|c|c|c|c|c|c|}
\hline & $\begin{array}{l}\text { TOC } \\
(\%) \\
\end{array}$ & $\begin{array}{c}\text { Formal dehyde } \\
\mathrm{b} p=101^{\circ} \mathrm{C}(\mathrm{a}) \\
(\mathrm{fg} / \mathrm{g}) \\
\end{array}$ & $\begin{array}{c}\text { Hydroqui none } \\
\mathrm{mp}=171^{\circ} \mathrm{C} \\
(\mathrm{fg} / \mathrm{g})\end{array}$ & $\begin{array}{c}\text { Ethylene } \\
\text { Glycol } \\
\text { bp }=197^{\circ} \mathrm{C} \\
(\mathrm{fg} / \mathrm{g}) \\
\end{array}$ & $\begin{array}{c}\text { MEK } \\
\mathrm{bp}=80^{\circ} \mathrm{C} \\
(\mathrm{fg} / \mathrm{g}) \\
\end{array}$ \\
\hline Control Sample & 0.9 & $<0.05$ & $<0.2$ & $<1$ & $<1$ \\
\hline \multicolumn{6}{|l|}{ At Soil Surface } \\
\hline $0 \mathrm{~cm}$ from block & (b) & (b) & (b) & (b) & (b) \\
\hline $23 \mathrm{~cm}$ from block & 0.9 & $<0.04$ & $<0.2$ & $<1$ & 0.9 \\
\hline $43 \mathrm{~cm}$ from block & 0.9 & $<0.04$ & $<0.2$ & $<1$ & $<1$ \\
\hline
\end{tabular}

$46 \mathrm{~cm}$ Below Surface

$0 \mathrm{~cm}$ from block

0.6

(b)

(b) $<0.05$

(b)

(b)

$<1$

(b)

$23 \mathrm{~cm}$ from block

(b)

0.06

$<0.2$

$<0.2$

$<1$

$<1$

$<1$

$92 \mathrm{~cm}$ Below Surface

$0 \mathrm{~cm}$ from block

(b)

$23 \mathrm{~cm}$ from block

(b)

(b)

$43 \mathrm{~cm}$ from block

$<0.05$

(b)

$\underset{\substack{(b) \\(b)}}{(b)}$

(b)

(b)

$<1 \quad 0.9$

$<1$

$<1$

Beneath Block

$0 \mathrm{~cm}$ from block

$23 \mathrm{~cm}$ from block

0.6

(b)

1.0

$<0.05$

1.0

$<0.05$

(b)

$<0.2$

$<0.2$

(b)

$<1$

$<1$

(b)

$<1$

$<1$

(a) As formic acid.

(b) Sample too small for analysis.

(c) Higher detection limit due to interferences in sample.

$\mathrm{mp}=$ melting point.

bp = boiling point.

One formaldehyde soil sample and two MEK soil samples exceeded the analytical detection 1 imits. The $100^{\circ} \mathrm{C}$ isotherm sample at a soil depth of $46 \mathrm{~cm}$ contained $0.06 \mathrm{ppm}$ formaldehyde, slightly above the $0.05 \mathrm{ppm}$ detection limit. Can 1 contained approximately $3 \mathrm{~g}$ of sodium formaldehyde bisulfate. The bottom of can 1 was placed at a depth of $42 \mathrm{~cm}$, so the $46-\mathrm{cm}$-deep sample was the most likely sample in which to find formaldehyde. However, the $0.06 \mathrm{ppm}$ concentration and absence of formaldehyde in other sample results indicates that the formaldehyde migration in the soil was limited. The formaldehyde concentration is several orders of magnitude below the 
$0.01 \%$ concentration limits set by the Washington State Dangerous Waste Regulations (WAC173-303) for carcinogens and halogenated hydrocarbons.

One surface soil sample and the $92-\mathrm{cm}$-deep $100^{\circ} \mathrm{C}$ isotherm soil sample contained $0.9 \mathrm{ppm}$ MEK (detection limit $1 \mathrm{ppm}$ ). The source of the MEK, can 4 (painting chemicals), was buried to a depth of $96 \mathrm{~cm}$. The MEK in the $92-\mathrm{cm}$ sample indicates that local migration of the MEK occurred in the soil near the can. The surface soil sample at the $100^{\circ} \mathrm{C}$ isotherm also showed a $0.9 \mathrm{ppm}$ MEK level. These data indicate some MEK migrated away from the active molten area out to a cooler region and then migrated to the soil surface. The two positive samples were very near the detection limit of the MEK analytical technique; consequently, little can be learned about the distribution pattern of the MEK in the soil. As with the formaldehyde results, the MEK concentrations in the soil were several orders of magnitude below the Washington State Dangerous Waste Regulations concentration limits. 
-

- 
CONCLUSIONS AND RECOMMENDATIONS

The engineering-scale experiment showed that ISV is appropriate for the destruction of several classes of containerized Hanford hazardous wastes. It can be concluded from the data taken during the heat up and destruction of the waste containers, and from the off-gas and soil analyses, that ISV may be used for organic and inorganic chemical disposal. Additional experimentation is required in the case of combustible liquid wastes.

Specific conclusions are as follows.

- The contents of the simulated waste containers were released in 40 to 80 minutes as evidenced by can temperature and pressure data. Extrapolated to the large-scale ISV unit, one 55-gallon drum of MEK or three 55-gallon drums of ethylene glycol could be destroyed in 40 minutes without exceeding the design criteria for the large-scale off-gas system. Since these conclusions are based on small (< 1 liter) samples, additional ISV pilot-scale and large-scale experimentation is required to verify off-gas system performance with larger containers of combustible organics.

Items requiring further clarification are --the effect of container size on release rate -the effect of partially filled containers on release rates --the fraction of combustion heat lost through the hood walls.

- Off-gas analyses for the major components of the simulated hazardous wastes indicate acceptable destruction and removal efficiencies by ISV. With an expected off-gas system removal efficiency of $99 \%$, the combined destruction/removal efficiency for formaldehyde, hydroquinone, ethylene glycol, and MEK were all above the $99.99 \%$ destruction/removal efficiency required by Federal regulations ( 40 CFR 264.343) for incineration of hazardous wastes. Measurement of the nitrate destruction efficiency was limited by the accuracy of the grab sample technique used to measure ${ }^{N O}{ }_{x}$ in the experiment. However, nitrate destruction efficiencies of $99.6 \%$ have been measured in 
previous ISV experiments. Sulfates were not readily destroyed by ISV, but off-gas scrubbing will bring the $\mathrm{SO}_{x}$ level below acceptable environmental release standards.

- Data from the soil analyses indicate that minor migration of the two most volatile chemicals (formaldehyde and MEK) occurred at the depth of the simulated waste containers out to the point where the soil reached approximately $100^{\circ} \mathrm{C}$. No migration of the higher molecular weight ethylene glycol or hydroquinone was detected. At soil concentrations of less than $1 \mathrm{ppm}$, the formaldehyde and MEK will not impose a hazard in the soil as defined by the Washington State Dangerous Waste Regulations (WAC173-303) for carcinogens and halogenated hydrocarbons. Trace quantities of MEK were also detected at the soil surface near the $100^{\circ} \mathrm{C}$ point. However, normal large-scale hood placement techniques will keep the organics from escaping into the atmosphere.

- Since Hanford dangerous waste disposal by ISV appears to be technically feasible, the economics of Hanford dangerous waste disposal should be investigated to determine if cost savings can be realized to enhance the effectiveness of the Hanford mission. Approximately $70 \%$ of the $22,000 \mathrm{~kg}$ of dangerous wastes shipped of fite from Hanford in 1985 were potentially processable by ISV (1985 OOE Hanford "Generator Annual Dangerous Waste Report," excluding a one-time shipment of $140,000 \mathrm{~kg}$ of spent antifreeze). This included $2300 \mathrm{~kg}$ of organic-water mixtures, $4200 \mathrm{~kg}$ of inorganics and inorganic-water mixtures, and $9200 \mathrm{~kg}$ of flammable liquids. 


\section{REFERENCES}

Buelt, J. L., and J. G. Carter. 1986a. Description and Capabilities of the Large-Scale In Situ Vitrification Process. PNL-5738, Pacific Northwest Laboratory, Richland, Washington.

Buelt, J. L., and J. G. Carter. 1986b. In Situ Vitrification Large-Scale Operational Acceptance Test Analysis. PNL-5828, Pacific Northwest Laboratory, Richland, washington.

Buelt, J. L., et al. 1987. In Situ Vitrification of Transuranic Wastes: An Updated Systems Evaluation and Applications Assessment. PNL-4800 Supplement 1, Pacific Northwest Laboratory, Richland, Washington.

Dept. of Energy-Richland Operations Office. 1985. Hanford Generator Annual Dangerous Waste Report. Form 4. Washington State Dept. of Ecology, Olympia, Washington.

Timmerman, C. L. 1986. In Situ Vitrification of PCB-Contaminated Soils. EPRI CS-4839. Prepared for Electric Power Research Institute, Palo A7to, California, by Pacific Northwest Laboratory, Richland, Washington. 


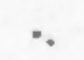




\section{DISTRIBUTION}

No. of

Copies

OFFSITE

30 DOE Technical Information Center

S. P. Mathur, DP -123

DOE Office of the Assistant

Secretary for Defense Programs A-227/GTN

Washington, DC 20545

M. McFadden

DOE Albuquerque Operations Office

P. 0. Box 5400

Albuquerque, MM 87185

J. McGough

DOE Albuquerque Operations Office

P.0. Box 5400

Albuquerque, NM 87185

M. J. Barainca/S. Henchberger

DOE Idaho Operations Office

550 Second Street

Idaho Falls, ID 83401

L. Lanni

DOE San Francisco Operations

1333 Broadway

San Francisco, CA 94612

W. H. Hannum

DOE West Valley Operations Office

P.0. Box 191

West Valley, NY 14171

S. Borys

Argonne National Laboratory

9700 South Cass

Argonne, IL 60439

R. Varma

Argonne National Laboratory

9700 South Cass Avenue

Argonne, IL 60439
No. of

Copies

D. R. Vissers

Argonne National Laboratory

9700 South Cass Avenue

Argonne, IL 60439

W. A. Freeby/J. L. Jardine

Bechtel National, Inc.

P.0. Box 3965

San Francisco, CA 94119

E. A. Jennrich

EG\&G Idaho

P.0. Box 1625

Idaho Falls, ID 83415

Jim Lowe

EG\&G Idaho

P.0. Box 1625

Idaho Falls, ID 83415

K. Davis

EG\&G Idaho, Inc.

P.0. Box 1625

Idaho Falls, ID 83415

D. Evans

EG\&G Idaho, Inc.

P.0. Box 1625

Idaho Falls, ID 83415

D. Nishimoto

EG\&G Idaho, Inc.

P.0. Box 1625

Idaho Falls, ID 83415

M. D. Boersma

E. 1. du Pont de Nemours Company

Savannah River Laboratory

Aiken, SC 29801

R. A. Shaw

Electric Power Research Institute

$3412 \mathrm{Hillview} \mathrm{Avenue}$

P.0. Box 10412

Palo Alto, CA 94304 
No. of

Copies

B. Andresen

Lawrence Livermore National Laboratory

P.0. Box 808

Livermore, CA 94550

L. Borduin

Lawrence Livermore National Laboratory

P.0. Box 808

Livermore, CA 94550

F. Harrison

Lawrence Livermore National Laboratory

P.0. Box 808

Livermore, CA 94550

F. Milanovich

Lawrence Livermore National Laboratory

P.0. Box 808

Livermore, CA 94550

R. A. Benson

Los Alamos National Laboratory

P.0. Box 1663

Los Alamos, NM 87545

C. K. Rofer

Los Alamos National Laboratory P.0. Box 1663

Los Alamos, NM 87545

C. L. Warner

Los Alamos National Laboratory

P.0. Box 1663

Los Alamos, NM 87545

T. H. Row

Oak Ridge National Laboratory

P.0. Box X

Oak Ridge, TN 37830

F. Homan

Oak Ridge National Laboratory

P.0. Box $Y$

Oak Ridge, TN 37830
No. of

Copies

L. Mezga

Oak Ridge National Laboratory

P.0. Box Y

Oak Ridge, TN 37830

D. Eyman

Oak Ridge National Laboratory

P.0. Box Y

Oak Ridge, TN 37830

B. Spalding

Oak Ridge National Laboratory

P.0. Box Y

Oak Ridge, TN 37830

P. T. Dickman

REECo

P.0. Box 642

Mercury, NV 89023

D. A. McGrath

REECO

P.0. Box 642

Mercury, NV 89023

K. V. Gilbert/P. G. Hagen

Rockwell International

Rocky Flats Plant

P.0. Box 464

Golden, C0 80401

K. McKinley

Joint Integration Office

Rockwell

Box 3150

Albuquerque, NM 87190

Technical Library

Sandia Laboratories

P.0. Box 5800

Albuquerque, NM 87185

M. Chu

Sandia National Laboratory

P.0. Box 5800

Albuquerque, NM 87185 
No. of

Copies

R. M. Cranwell

Sandia National Laboratory

P.0. Box 5800

Albuquerque, NM 87185

N. R. Ortiz

Sandia National Laboratory P.0. Box 5800, Div. 6430

Albuquerque, NM 87185

I. Aok i

U.S. Department of Energy Idaho Operations office

550 Second Street

Idaho Falls, ID 83401

J. R. Bol and

U.S. Department of Energy

Nevada Operations Office

P.0. Box 14100

Las Vegas, NV 89114

R.T.A. Bredderman

U.S. Department of Energy

San Francisco Operations Office

1333 Broadway

Oakland, CA 94612

D. Browning

U.S. Department of Energy

Savannah River Operations

P.0. Box A

Aiken, SC 29808

F. Fong

U.S. Department of Energy

San Francisco Operations

1333 Broadway

Oak 1 and, CA 94612

R. A. Koening

U.S. Department of Energy

Los Alamos National Laboratory

P.0. Box 1663

Los Alamos, NM 87545
No. of

Copies

D. Krenz

U.S. Department of Energy

Albuquerque Operations Office

P.0. Box 5400

A1buquerque, NM 87115

C. Soden

U.S. Department of Energy

Albuquerque Operations

P.0. Box 5400

Albuquerque, M 87115

Office of Assistant Manager

U.S. Department of Energy

P.0. Box E

Oak Ridge, TN 37831

C. H. George

U.S. Department of Energy

Office of Defense Waste and

Transportation Management

DP-124 (GTN)

Room 1921

Germantown, MD 20874

W. Griffing

Technical Management Division

Waste Management Group

U.S. Department of Energy

Chicago Operations Office

9800 South Cass Avenue

Argonne, IL 60439

R. B. Craig

U.S. DOE-HAZWRAP

Box Y

Oak Ridge, TN 37830

J. C. Parker

U.S. DOE -HAZWRAP

Box Y

Oak Ridge, TN 37830

J. L. Petty

U.S. DOE -HAZWRAP

Box Y

Oak Ridge, TN 37830 
No. of

Copies

J. J. Barrich III

U.S. Environmental Protection Agency

1200 6th Avenue

MS HW-113

Seattle, WA 98101

R. J. Courson

U.S. Environmental Protection Agency

12006 th Avenue

MS ES -096

Seattle, WA 98101

C. Findley

U.S. Environmental Protection Agency

12006 th Avenue

MS HW-111

Seattle, WA 98101

J. Shafer

U.S. Environmental Protection Agency

1200 6th Avenue

MS HW-113

Seattle, WA 98101

W. Giese

U.S. Environmental Protection Agency

999 18th St.

Suite 500

Denver, CO 80202-2405

L. Johnson

U.S. Environmental Protection Agency

$99918 \mathrm{th}$ St.

Denver, C0 80202-2405

T. Hauser

U.S. Environmental Protection Agency

26 w. St. Claire St.

Cincinnati, $\mathrm{OH} 45268$
No. of

Copies

C. Dial

U.S. Environmental Protection Agency

26 W. St. Claire St.

Cincinnati, $\mathrm{OH} 45268$

R. $\mathrm{Hill}$

U.S. Environmental Protection Agency

26 W. St. Claire St.

Cincinnati, $\mathrm{OH} 45268$

D. Senning

U.S. Environmental Protection

Agency

26 W. St. Claire St.

Cincinnati, $\mathrm{OH} 45268$

Librarian

Westinghouse Electric Corporation

Technical Library

P.0. Box 40039

Albuquerque, NM 87196

J. M. Pope

West Valley Nuclear Services Company

P.0. Box 191

West Valley, NY 14171

M. L. Walker

Assistant Secretary of Environment, Safety and Health

U.S. Department of Energy

1000 Independence Avenue S.W. Washington, D.C. 20585

ONSITE

Battel le-Seattle (BSCR)

R. H. Lovely 
No. of

Copies

7 DOE Richland Operations Office

E. A. Bracken

J. R. Hunter

N. T. Karagianes

W. Schulze

M. W. Shupe

J. J. Sutey

J. D. White

13 Westinghouse Hanford Company

R. J. Cash

R. G. Cowan

T. E. Dabrowski/W. J. Kyriazis

K. A. Gasper

N. W. Kirch

R. E. Lerch

D. E. McKinney

J. H. Roecker

T. B. Venziano

J. D. Watrous

D. D. Wodrich

R. J. Wojtasak

File Copy
No. of

Copies

42 Pacific Northwest Laboratory

W. Ballard

W. F. Bonner

J. L. Buelt

H. C. Burkholder

J. G. Carter

D. B. Cearlock/w. R. Wiley

T. Claudson

V. F. FitzPatrick

T. L. Gilbride

J. E. Hansen

M. S. Hanson

J. N. Hartley

S. S. Koegler (10)

R. C. Liikala

J. L. McElroy

T. McLaughlin

S. J. Mitchell

I. C. Nelson/P. Bramson

K. H. Oma

C. Palmer

J. V. Robinson

B. L. Steelman

S. L. Stein

T. L. Stewart

J. Straalsund

C. L. Timmerman

Technical Report Files (5)

Publishing Coordination (2) 


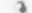

